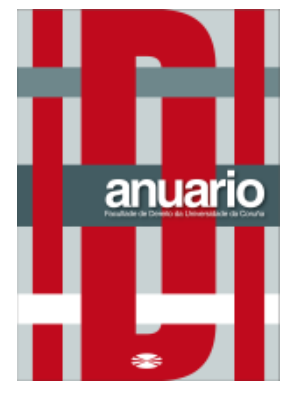

Anuario da Facultade de Dereito da Universidade da Coruña

Vol. 22 (2018), pp. 97-137

ISSNe: 2530-6324 || ISSN: 1138-039X

DOI: https://doi.org/10.17979/afdudc.2018.22.0.5177

\title{
MUNICIPIUM E MUNICIPALIZACIÓN NA ASTURIA ET CALLAECIA ROMANAS
}

\author{
MARTÍN FERNÁNDEZ CALO \\ Licenciado e doutorando en Historia \\ Universidade de Santiago de Compostela
}

Resumo: Analízase a implantación histórica do municipium romano na Asturia et Callaecia a través da reunión e crítica exhaustiva do seu rexistro documental, fundamentalmente de natureza epigráfica. Constátase así un proceso xeral de municipalización entre as comunidades ástur-galaicas, canda certas irregularidades locais.

Palabras chave: Asturia et Callaecia romanas, municipium, institucións romanas, ordines decurionum, maxistraturas municipais, ius Latii, historia institucional.

Abstract: This paper analyzes the historical implantation of Roman municipium in Asturia et Callaecia, by the comprehensive gathering and critique of its available record, basically of epigraphic nature. A general process of municipalization can be thereby verified among the Astur and Gallaeci communities, along with some local irregularities.

Keywords: Roman Asturia et Callaecia, municipium, Roman institutions, ordines decurionum, municipal magistracies, ius Latii, institutional history. 
SUMARIO: I. INTRODUCIÓN. II. CONCEPTUALIZACIÓN DO MUNICIPIUM ROMANO. III. HISTORIOGRAFÍA DO MUNICIPIUM ÁSTUR-GALAICO. IV. REXISTRO DOCUMENTAL. 1. Epítetos imperiais comunitarios. 2. A tribo Quirina. 3. Ordines decurionum. 4. Cargos municipais. 5. Títulos oficiais comunitarios. 6. Indicios materiais do proceso. V. INTERPRETACIÓN. 1. Diverxencias intra-rexionais. 2. O carácter gradual do proceso. VI. CONCLUSIÓNS.

\section{INTRODUCIÓN}

Na Asturia et Callaecia, o derradeiro terzo do século I d.C., aparentemente continuísta verbo ao artellamento político-administrativo asentado por Augusto, viuse con todo marcado polo acceso á púrpura imperial de Vespasiano, fundador da dinastía Flavia, e pola súa gratificación xeral do privilexio xurídico do ius Latii a toda a península ibérica. Non se alterou a dependencia provincial verbo á Hispania citerior; reforzáronse os sectores económicos —nomeadamente a minaría - xa previamente controlados polo Estado; abríronse novas calzadas, reproducindo o interese que xa Augusto amosara en interconectar o territorio; e se neste intre se instauraron os conuentus iuridici «clásicos» de Astorga, Braga e Lugo ${ }^{1}$, isto fíxose sobre a base das propias tres cidades fundadas por Augusto, xa dotadas dende moito antes dun relevante papel político e administrativo. Emporiso, foi no interior das propias ciuitates ástur-galaicas gratificadas polo antedito privilexio imperial, refrendadas a súa lei e as súas institucións polo dereito romano, integrados os seus corpos cívicos na ampla e desdebuxada «cidadanía latina», recoñecida a súa entidade constitucional como rei publicae- onde se van producir as máis transcendentais innovacións políticas deste século e mesmo de toda a Romanidade. En efecto, é aquí de onde arrinca a «municipalización»: o proceso de reformulación constitucional máis decisivo do dominio romano na Asturia et Callaecia, e se cadra de toda historia institucional posterior desta dobre rexión.

A municipalización é un tema que ten xerado pouco interese historiográfico, pero si algunha significativa controversia, no ámbito específico da Asturia et Callaecia. Este dobre corónimo alude aos tres conuentus iuridici noroccidentais - asturicense, bracarense e lucense - da provincia Hispania citerior, que conformaron na Alta Romanidade, cando se promulgou a latinización xurídica, un ámbito xeográfico significativamente singularizado e interrelacionado a nivel administrativo, pero tamén noutros moitos aspectos sociais, culturais e materiais (véxase fig. 1$)^{2}$. Tales aspectos definen uns nidios condicionantes estruturais que teñen xogado un papel decisivo na valoración tradicionalmente «restritiva» da influencia romana, concibíndose este un espazo singularmente refractario á «romanización». Por suposto, esta circunstancia afecta tamén á interpretación da súa historia institucional. Máis do que atender á plasmación rexional do municipium, a investigación histórica adoitou centrar as súas

1 Noutro traballo teño afondado na incerteza cronolóxica e posibilidade dunha orixe flaviana desta institución: véxase M. FERNÁNDEZ CALO, A organización político-administrativa de Galicia na Antigüidade (séculos II a.C.-VIII d.C.), tese de licenciatura inédita (Universidade de Santiago de Compostela), 2015, páx. 65-66.

2 O estudo máis completo arredor dos lindeiros conventuais ástur-galaicos segue a ser o de A. TRANOY, La Galice Romaine: recherches sur le nord-ouest de la péninsule ibérique dans l'Antiquité, Paris, 1981, páxs. 153 e segs. Na cartografía que acompaña este traballo cíngome a reproducir os meus resultados propios, simple actualización do anterior, expostos en M. FERNÁNDEZ CALO, $A$ organización..., cit., páxs. 67-68 e 223. 
pescudas en cómo o entramado político puido desenvolverse en ausencia do mesmo. $\mathrm{O}$ carácter marcadamente rural da rexión, a aparentemente forte remanencia da súa cultura autóctona tradicional, a pobreza da súa documentación..., nunha palabra, o relativo subdesenvolvemento estrutural da Asturia et Callaecia romanas verbo a outros ámbitos veciños, teñen redundado comunmente no desinterese ou matización do seu proceso de municipalización. Mais este preconceito non é o único factor que ten empecido a investigación do municipium ástur-galaico. En efecto, como tamén teño denunciado noutra achega recente ${ }^{3}$, a investigación en Historia romana ten sobredimensionado tradicionalmente neste caso particular toda súa atención ao período alto-imperial en detrimento do baixo-imperial, malia seren baixo-imperiais algúns poucos, pero dos máis significativos, testumuños do municipium ástur-galaico. Ningún deles xogou o máis mínimo papel nas avaliacións recentes da municipalización ástur-galaica. Finalmente, tamén influíron por moito tempo as interpretacións «reduccionistas» da latinización xurídica flaviana, hoxe xa xeralmente superadas pola historiografía; o que con todo non motivou unha relectura específica — non canda menos unha exhaustiva - para a Asturia et Callaecia.

O presente estudo pretende desenvolver esta relectura, a prol da actualización do rexistro do municipium ástur-galaico e da súa interpretación arredada dos preconceitos restritivos que tradicionalmente dominaron a historiografía arredor deste tema. Propoño definir con este fin o concepto de municipium, dende unha perspectiva xenérica, como base teórica do estudo (§II), a través do que avaliarei en primeiro lugar as achegas historiográficas precedentes (§III). De seguido, pasarei á reunión e análise do rexistro documental da Asturia et Callaecia, o verdadeiro miolo do estudo (§IV). Isto motivará unha interpretación global da implantación histórica do municipium nesta rexión $(\S \mathrm{V})$, que será finalmente sintetizada nas conclusións que pechan este artigo (§VI).

\section{CONCEPTUALIZACIÓN DO MUNICIPIUM ROMANO}

Municipium e municipalización poden ter acepcións diversas. En termos históricos, o proceso ao que tentaremos achegarnos no presente estudo refírese a constitución das comunidades locais en municipia, o que en esencia se reduce á adopción, segundo diferentes ritmos, dunha serie de institucións e garantías xurídicas entre as comunidades locais de todo o Imperio Romano, e nomeadamente do Occidente latino. Isto abrangue procesos potencialmente dispares, condicionados tanto polo desenvolvemento políticoinstitucional previo como polas circunstancias das innovacións lexislativas romanas.

Verbo ao primeiro factor, na Asturia et Callaecia existiu un substrato institucional potencialmente proclive para a adopción do municipium. Segundo teño amosado nun meu estudo recente, o rexistro de institucións pre-municipais ástur-galaicas certifica a adopción das estruturas básicas da república antiga en boa parte das comunidades locais da rexión, embora en convivencia coa persistente organización étnica doutras ${ }^{4}$. Xa no período xulio-claudiano se acadara, pois, un nivel de desenvolvemento institucional potencialmente proclive para a adopción do municipium como consecuencia dos privilexios imperiais.

No segundo factor antes aludido, pola súa banda, na Asturia et Callaecia atopamos a

3 M. FERNÁNDEZ CALO, "Transformacións e permanencia do municipium na Gallaecia barixo-romana (séculos III-V)”, CEG, LXIV, 130, 2017, páx. 17.

4 M. FERnÁNDEZ CALO, "O desenvolvemento político pre-municipal dos pobos galaicos", Gallaecia, $35,2016$. 
latinización flaviana. O municipium romano, en efecto, é consecuencia dun privilexio xurídico concedido polo senado ou o emperador, que na península ibérica, agás nas comunidades gratificadas antes, coincide co Edicto de Latinidade flaviano, na década do 70 d.C. Non existe unha ampla evidencia documental directa arredor deste transcedental acto político, apenas constatada pola concisa pero rotunda referencia de Plinio o Vello, que identifica ao emperador Vespasiano (69-81 d.C.) como doador e a totalidade da península ibérica (uniuersae Hispaniae) como beneficiaria ${ }^{5}$. Esta referencia foi e segue a ser moi discutida pero hai xa varias décadas que o consenso historiográfico, ao abeiro das notábeis transformacións xurídicas e materiais percibidas na Hispania post-flaviana, apunta a que a latinización se estendeu a todas as ciuitates hispanas e estivo adicionalmente asociada á concesión da cidadanía romana ex uirtute aos seus maxistrados municipais ${ }^{6}$.

Os efectos da latinización xurídica foron multifacéticos, pero só un deles se vencella directamente ao propósito xeral do presente estudo: o efecto puramente «constitucional», a «municipalización». Neste senso, o ius Latii fixo transitar ás comunidades gratificadas da submisión política ao recoñecemento da súa soberanía formal nunha relación xurídica teoricamente simétrica con Roma ${ }^{7}$, e do axuste ao dereito romano dos seus iura e instituta locais ${ }^{8}$. Isto non carece de relevancia no noso ámbito de estudo, pois, como ten insistido J. Andreu Pintado, a natureza xurídica do municipium limítase á sanción lexislativa romana do auto-goberno comunitario ${ }^{9}$ :

O municipium é o marco xurídico e institucional no que unha serie de habitantes, os municipes, participan dos dereitos, deberes e funcións típicas derivadas do exercicio dunha serie determinada de cargos ou munera. [...] En senso xurídico, un municipium existe cando existen individuos capaces de asumiren (capere) os munera, e, no caso dos municipia nados ao abeiro do Latium, cando Roma recoñece que as súas institucións se axustan a dereito e xa que logo o seu ordenamento institucional e de xestión se asemella — progresivamente a partires deste intre - aos usos romanos.

A municipalización pode ser entendida, xa que logo, como un efecto xurídico automático da latinización, independentemente de toda transformación constitucional e mesmo institucional inmediata nas comunidades afectadas. Porén, esta definición «xurídica» non ten ningunha aplicación directa para unha perspectiva endóxena da municipalización, focalizada nestas mesmas comunidades. Neste senso, que a lei romana as recoñecese de iure como municipia non significa que estas recoñecesen a devandita lei coma a súa fonte primaria de dereito. A latinización abría, en realidade, un lapso de adaptación desta lei nas estruturas autóctonas, e isto será o que defina, dende unha perspectiva endóxena, a municipalización. En efecto, este proceso ten outra vertente, a «institucional»: a transformación das institucións autóctonas como parte da influencia dun modelo constitucional exóxeno. L. Lamoine, reproducindo o parecer da

5 Plinio o Vello, Naturalis Historia, III, 30.

6 J. MANGAS MANJARRÉS, Leyes coloniales y municipales de la Hispania romana, Madrid, 2001, páxs. 14-15; J. ANDREU PINTADO, "Latinización y municipalización en el Alto Imperio: nuevas perspectivas para el estudio de la Hispania de los flavios", en F. Beltrán Lloris (ed.), Antiqua Iuniora: en torno al Mediterráneo en la Antigüedad, Zaragoza, 2004; íd., Edictum, municipium y lex: Hispania en época Flavia (69-96 d. C.), Tudela, 2004; M. J. BRAVO BOSCH, "Latium maius versus Latium minus en la Hispania flavia", AFDUDC, 13, 2009.

7 T. J. CORNELl, T. J., "Rome and Latium to 390 B.C.”, CAH, VII, 2a parte, Cambridge, 1989, páx. 264.

8 J. ANDREU PINTADO, "Mitos y realidades sobre la municipalización flavia en Lusitania", en J.-G. Gorges, J. d'Encarnação, T. Nogales Basarrate, A. Carvalho (coords.), Lusitânia romana: entre o mito e a realidade, Cascais, 2009, páx. 498.

9 J. ANDREU PINTADO, “Latinización...”, cit., páx. 202. Tradución do castelán orixinal. 
investigación francesa arredor do mesmo problema na Galia romana, ten definido concisamente estoutra acepción ${ }^{10}$ :

Por municipalización entenderemos o establecemento de formas de organización cívica, semellantes ás que existían polo mesmo tempo na Italia romana, a iniciativa das autoridades romanas ou coa súa aquiescencia.

As dúas citas reproducidas sitúannos perante dous aspectos parciais —xurídico e institucional - da municipalización, que han de seren valorados conxuntamente para unha definición íntegra deste proceso histórico. A nivel institucional, a municipalización non foi simultánea á latinización xurídica ${ }^{11}$, pois loxicamente as ciuitates beneficiarias deste privilexio mantiveron intactas as súas estruturas socio-políticas anteriores, encetando só gradualmente e dende $\operatorname{logo}$ a posteri a adaptación local do réxime xurídico-legal adquirido; e, se acaso, a súa transformación constitucional. Unha última posibilidade, «mixta», é que esta mutación constitucional incidise unicamente en certas ciuitates especialmente susceptíbeis a facelo namentres outras, embora tamén obxecto do privilexio xurídico, se lles adscribían, resolvendo nelas o exercicio das maxistraturas e a materialización de certos dereitos ${ }^{12}$. Neste caso, a municipalización sería plena nunhas comunidades pero só parcial noutras, por dependeren das anteriores para o seu desenvolvemento institucional.

De calquera xeito, fosen cáles foren os resultados, só na conxunción de ambos os aspectos aludidos é posíbel identificarmos a dimensión «histórica» da municipalización: o proceso de constitución das ciuitates anteriores en comunidades de dimensión local e réxime político republicano de influencia romana - aspecto institucional- recoñecidas e integradas no dereito romano - aspecto xurídico.

\section{HISTORIOGRAFÍA DO MUNICIPIUM ÁSTUR-GALAICO}

Verbo á plasmación deste proceso xurídico-institucional na Asturia et Callaecia, a historiografía admite xeralmente a influencia do ius Latii na difusión e consolidación de novas formas políticas locais; embora a asimilación disto cun proceso de constitución das ciuitates como municipia, ou «municipalización», adoita matizarse amplamente, desbotándose a súa incidencia xeneralizada ou admitíndoa estritamente nas entidades con epítetos imperiais, ou mesmo só nas principais cidades ${ }^{13}$. Estas posturas adoitan fuxir da fulcral cuestión do réxime organizativo que as comunidades non municipais terían adoptado logo da latinización en ausencia do municipium. Ao meu ver, a lectura

10 L. LAmoine, Le pouvoir local en Gaule romaine, Paris, 2009, páx. 11. Tradución do francés orixinal.

11 P. LE RouX, "Las ciudades de la Callaecia romana durante el Alto Imperio", Gerión, 14, 1996, páx. 368; F. J. LOMAS SALMONTE, "Consideraciónes sobre las civitates del cuadrante noroccidental de la Península Ibérica”, en A. Rodríguez Colmenero (coord.), Los orígenes de la ciudad en el noroeste hispánico, vol. I, Lugo, 1998, páx. 186; KREMER, D., Ius Latium: le concept de droit latin sous la république et l'empire, Paris, 2007, páx. 181; G. ALFÖLDY, "Spain”, CAH, XI, Cambridge, 2000, páxs. 450-451; E. ORTIZ DE URBINA, Las comunidades hispanas y el derecho latino: observaciones sobre los procesos de integración local en la práctica político-administrativa al modo romano, VitoriaGasteiz, 2000, páx. 126.

12 J. GonZÁLEZ FERNÁNDEZ, "Ius Latii y Lex Flavia municipalis", Mainaké, 23, 2001, páxs. 122-123; J. ANDREU PINTADO, "Latinización...”, cit., páx. 203.

13 A. Tranoy, La Galice..., cit., páx. 205; G. Pereira Menaut, "Los castella y las comunidades de Gallaecia”, Zephyrus, 34-35, 1982, páxs. 263-265; P. LE RouX, "Las ciudades...”, cit., páx. 368; F. J. LOMAS SALMONTE, “Consideraciones...”, cit., páxs. 184-185; J. GONZÁLEZ FERNÁNDEZ, "Ius Latii...”, cit., páx. 123; A. M. SUÁREZ PIÑEIRO, A romanización..., cit., páx. 64; D. FonSECA SORRIBAS, "El municipium romano de Aquae Flaviae y su problemática”, Anesteria, 1, 2012, páx. 523. 
máis depurada é a interesante proposta de J. González Fernández, quen do carácter maioritariamente rural das ciuitates do noroeste hispano ten inferido unha organización político-administrativa semellante ao das gentes alpinas, das que se documenta teren sido adscritas fiscal e institucionalmente a uns poucos municipia, as principais cidades, en réxime de adtributio $^{14}$.

En todas estas interpretacións «restritivas» xoga a ineludíbel parcialidade do rexistro, pero tamén as lecturas reduccionistas do concepto municipium. De feito, o «pesimismo» interpretativo resultante ten motivado a subestimación do propio rexistro, como pode ser, moi especialmente, a común matización do carácter municipal das cidades ásturgalaicas con epítetos imperiais, como veremos nun apartado específico máis adiante. Pero tal subestimación afectou mesmo a algunhas evidencias claras e inequívocas de institucións municipais. Así, seguindo os estudos de B. Galsterer-Kröll arredor da permanencia constitucional nas provincias «célticas» do Imperio Romano, G. Pereira Menaut chegou a obstar mesmo o carácter municipal de maxistraturas tan paradigmáticas coma os duumuiri de Auobriga e da ciuitas Limicorum ${ }^{15}$. Xa polas mesmas datas J. Santos promoveu a moderación desta postura, o que con todo se traduciu igualmente nunha valoración moi restritiva da municipalización ${ }^{16}$.

Este «pesimismo» historiográfico derivou nun moi escaso interese específico pola reunión e valoración exhaustiva do rexistro documental implicado. Existen varias achegas ao respecto, pero nunca monográficas, isto é, centradas especificamente no tema da municipalización ástur-galaica. Entre elas cómpre citarmos a de A. Tranoy, que se ocuparía deste tema, analizando exhaustivamente as fontes dispoñíbeis, dentro dunha monografía máis ampla da Galiza romana. As súa conclusión é que os municipia romanos da Asturia et Callaecia foron Aquae Flauiae, Asturica Augusta, Bracara Augusta, Brigiaecum, Lancia, a ciuitas Limicorum e Lucus Augusti ${ }^{17}$. Máis recente, e tamén máis completa, embora desta volta non especificamente centrada na Asturia et Callaecia senón na municipalización flaviana de toda a península ibérica, é a achega de J. Andreu Pintado, quen, afondando e sistematizando a valoración do rexistro documental, ten clasificado as comunidades ástur-galaicas segundo a certeza da súa constitución municipal. Para el serían municipia «seguros» Aquae Flauiae, Asturica Augusta, Bergidum Flauium, Bracara Augusta, Brigiaecum, Flauionauia, Lancia e a ciuitas Limicorum; pero «probábeis», ademais, Lucus Augusti, Legio VII Gemina e a ciuitas Zoelarum, considerando «dubidoso» o carácter municipal doutras once ciuitates pola parcialidade da documentación implicada ${ }^{18}$. Este estudo destaca, se cadra máis mesmo ca pola meirande exhaustividade e precisión metodolóxica, polas súas premisas máis «optimistas» arredor da municipalización ástur-galaica.

Non podería, en fin, deixar sen referir as miñas propias achegas verbo a este tema particular. Recentemente teño adicado dous estudos monográficos a cadanseu período da historia institucional galaico-romana: o pre-municipal e o baixo-imperial, balizando, xa que logo, os dous extremos do proceso que nos ocupa agora ${ }^{19}$. No primeiro estudo, como xa apuntei con anterioridade, puiden verificar a implantación de estruturas

14 J. GONZÁLEZ FERNÁNDEZ, “Ius Latii...”, cit., páxs. 122-123.

15 B. GALSTERER-KRÖLl, "Zum ius Latii in den keltischen Provinzen des Imperium Romanum", Chiron, 3, 1979; G. PEREIRA MenAut, "Los castella...”, cit., páx. 264.

16 J. SANTOS YANGUAS, Comunidades indígenas y administración romana en el noroeste hispánico, Bilbao, 1985, páxs. 87 e ss.

17 A. TranOY, La Galice..., cit., páx. 205.

18 J. ANDREU PINTADO, Edictum..., cit., páxs. 141-144 e 147.

19 Respectivamente, M. FERNÁNDEZ CALO, “O desenvolvemento...”, cit.; íd., “Transformacións...”, cit. 
republicanas entre as comunidades étnicas do noroeste hispánico antes da súa latinización xurídica. No segundo, a avaliación de referencias tardo-antigas de municipia galaicos foi o paso preliminar para evidenciar a permanencia do réxime municipal ata datas serodias e interpretar ao seu abeiro as noticias históricas dos períodos baixo-romano e suevo temperán na Callaecia. Son estes estudos, que como vemos encadrelan con outros xa tendentes á valoración optimista da municipalización ástur-galaica, os que verdadeiramente motivan, a título persoal, a presente proposta de investigación.

\section{REXISTRO DOCUMENTAL}

O rexistro documental da municipalización ástur-galaica, dada a relativa pobreza da epigrafía romana da rexión, é moi fragmentario. Rara vez se dispón de datos complementarios referentes a unha mesma ciuitas, agás para as principais cidades. Con todo, o devandito rexistro non se limita á epigrafía, e tampouco ao período alto-imperial do que arrinca a municipalización. Non se pretende desenvolver aquí unha valoración individualizada de cada ciuitas, pois a propia parcialidade do rexistro para a meirande parte delas desacredita tal resolución metodolóxica. Proponse, en troques, a identificación global de varios indicativos documentais da municipalización, a partires de cuxa síntese extraermos unha noción global da incidencia efectiva deste proceso.

Omitiranse aquí algúns indicativos empregados nalgunhas achegas precedentes, de escasa relevancia para o noso obxecto inmediato. Así, a notábel difusión do nomen Flauius na onomástica ástur-galaica ${ }^{20}$ pode ser sen dúbida considerado un efecto do pulo flaviano na asimilación socio-cultural deste ámbito a través da municipalización, pero non máis do que os nomina romanos e imperiais presentes tanto antes coma despois da dinastía Flavia. Do mesmo xeito, as referencias de Claudio Ptolomeo a póleis $^{21}$, malia se teren empregado como indicativo complementario da urbanización e municipalización hispana ${ }^{22}$, agochan en realidade unha ampla diversidade de tipoloxías habitacionais $^{23}$. Xa a nivel arqueolóxico, o togado de Los Cabos, Pravia, baixorrelevo dunha estela da que se perdeu a práctica totalidade do campo epigráfico ${ }^{24}$, ten sido interpretado nalgunhas achegas como proba do estatuto municipal de Flauionauia $^{25}$. Semellante derivación dunha simple representación iconográfica semella excesiva, toda vez que na propia Callaecia existe un testemuño potencialmente análogo, a estela de Crecente $^{26}$, probabelmente do século I d.C., onde no campo escultórico se representa unha familia enteira con indumentaria romana, e pola contra no campo epigráfico se reproduce unha origo «castrexa» ou «pre-municipal», con referencia a un castellum e xa que logo incompatíbel co municipium. En Flauionauia, como se amosará, é o epíteto

20 P. LE RouX e A. Tranoy, "Rome et les Indigènes dans le Nord-Ouest de la Péninsule Ibérique: problèmes d'épigraphie et d'histoire", $M C V, 9,1973$, páxs. 224-225.

21 Claudio Ptolomeo, Geōgraphikè Hyphégēsis, II, 6.

22 J. ANDREU PINTADO, Edictum..., cit., páxs. 147ss.

23 Segundo teño sinalado expresamente para o caso ástur-galaico: M. FERNÁNDEZ CALO, "Plinio, o Parroquial Suevo, e a evolución estrutural do poder local galaico na Antigüidade", Gallaecia, 34, 2015, páx. 184.

24 ERA, 20.

25 N. SAntos YAnguAS, "Flavionavia: una ciudad romana en la frontera del Imperio", Stud. Hist.-Ha . antig., 16, 1998, páxs. 134-135; J. ANDREU PINTADO, Edictum..., cit., páx. 150.

$26 A E 1997,863$. 
imperial, non a simple escultura dun togado, o que apoia o seu rango municipal. Polo demais, moitos outros documentos epigráficos e arqueolóxicos poden servir de indicadores concretos da municipalización. Así, constan a celebración de xogos gladiatorios e a existencia de grupos sociais privilexiados dentro da cidadanía latina en cadansúa inscrición flaviense ${ }^{27}$. Pola súa banda, entre as evidentes estruturas públicas dalgúns núcleos urbanos, eludindo conscientemente as principais cidades, pódense citar as termas de Tongobriga, centro urbano secundario e de orixe castrexa ${ }^{28}$. Cumpriría dende logo adscribirmos testemuños coma estes a un estilo de vida urbano tipicamente romano, indicios ineludíbeis do funcionamento municipal das comunidades implicadas. Tales testemuños, esenciais para a investigación da historia social destas comunidades, afástanse con todo da incardinación temática expresamente institucional e o propósito de globalidade do presente estudo.

Aínda sen desemerecermos os indicadores referidos, existen outros de testemuño máis sistemático e implicacións máis directas no aspecto político-institucional, e xa que logo máis útiles para o recoñecemento da implantación municipal na Asturia et Callaecia. Estes son os que coido que mellor poden satisfacer este cometido:

$1^{\circ}$. - os epítetos imperiais que distinguiron a algunhas comunidades;

$2^{\circ}$. - a adscrición tribal dos cidadáns romanos da Asturia et Callaecia;

$3^{\circ}$. - as referencias a ordines decurionum;

$4^{\mathrm{o}}$. - o testemuño de cargos municipais;

$5^{\circ}$. - a denominación oficial dos réximes políticos locais;

$6^{\circ}$. - a incidencia dunha xeneralizada reformulación constitucional, especialmente na Callaecia castrexa, a partires da latinización.

Propoño, pois, desenvolver a continuación a análise exhaustiva de cada un destes indicadores, valorando individualizadamente as súas implicacións para o tema específico no que se centra o presente estudo, co propósito de desenvolver a partires disto unha posterior interpretación conxunta.

\section{Epítetos imperiais comunitarios}

A dotación dun epíteto dinástico para unha comunidade supón un indicio ineludíbel de ter sido fundada ou promovida xuridicamente por iniciativa imperial. Na Asturia et Callaecia existen dúas familias de cidades con estes epítetos: a augustea e a flaviana. A isto podería engadirse, ademais, o isolado, e incerto, caso hipoteticamente claudiano de Klaudiomerion (véxase fig. 2).

A familia augustea enxerga o posíbel desenvolvemento municipal da Asturia et Callaecia antes do Edicto de Latinidade vespasianeo. A fundación no remate do século I a.C. de Astorga (Asturica Augusta), Braga (Bracara Augusta) e Lugo (Lucus Augusti) vencellouse a unha mesma iniciativa imperial de artellamento urbano no noroeste da provincia Hispania citerior, que convertiría dende aquela estas tres localidades nas principais referencias do poder imperial e a cultura romana para cadansúa contorna indíxena $^{29}$. Non existen datos positivos cos que identificarmos o réxime político destas

27 Respectivamente, CIL II, 2473 e $4787=A F$, 599, con mención de equites.

28 Véxase L. A. T. DiAs, “Tongobriga”, en A. Rodríguez Colmenero (coord.), Los orígenes..., cit., vol. II.

29 A. TRANOY, "Permanences indigènes et romanisation en Galice", en AA.VV., Actas do I Congreso Internacional da Cultura Galega, Santiago de Compostela, 1992, páx. 78; P. LE RouX, "Las 
cidades no seu primeiro século de vida, e a cotío téndese a concibir a súa municipalización flaviana. A orixe militar presumida canda menos para Astorga e Lugo, que terían servido de base campamental a cadansúa lexión $-X$ e VI respectivamente-, obstaría a noción dun goberno civil estruturado dende a súa fundación. Pero o temperán abandono militar destas localidades non rematou coa súa ocupación civil. Neste senso, poderíase especular a designación dun praefectus ou funcionario imperial encargado do seu goberno civil; pero esta solución atopa o mesmo nulo apoio documental cá noción dun goberno municipal pre-flaviano. É certo que se testemuña dun xeito moi fragmentario a vixencia, se cadra flaviana, duns praefecti Callaeciae e Asturiae ${ }^{30}$; pero son estas figuras vencelladas ao ámbito militar e, canda menos no primeiro caso - no segundo si que se podería adscribir especificamente a Astorga-, a unha xurisidición $a$ priori máis ampla do que unha simple localidade ${ }^{31}$. Dende logo, un goberno civil estruturado nestas cidades, mesmo de estatuto latino dende moito antes da dinastía Flavia, devén nunha solución factíbel ${ }^{32}$. Isto, embora non implique que estas cidades obtivesen expresamente o título municipal, si vencella o seu funcionamento político ordinario ao que no presente estudo se entende, segundo se desenvolveu no seu momento, por réxime municipal: lei romana e institucións civís romanas.

Despois das fundacións augusteas, podería fornecerse o caso de Klaudiomérion, dada a súa aparente correspondencia léxica co nomen do emperador Claudio (41-54 d.C.), como cidade fundada ou promovida por iniciativa imperial antes do Edicto de Latinidade $^{33}$. Con todo, a súa historicidade resulta dende logo dubidosa. En efecto, Klaudiomérion consta unicamente por Ptolomeo ${ }^{34}$, autor do século II, sendo eludida en todas as descricións xeográficas anteriores; e nomeadamente na corografía marítima de Plinio o Vello ${ }^{35}$, escrita inequivocamente post quem á hipotética orixe claudiana desta cidade. O propio topónimo, así como aporta o indicio para o seu vencellamento a unha promoción imperial, induce tamén a sospeita de que a semellanza gráfica, en grego, con Glandómiron, citado na mesma fonte ${ }^{36}$ e testemuñado por documentación complementaria $^{37}$, reduza o topónimo claudiano a un simple erro, por duplicación, na súa transcrición textual. É salientábel, por último, que o mesmo Ptolomeo adscriba esta pólis aos Ártabroi, o que podería asimilala a Flauium Brigantium. Cómpre pensar na dobre reformulación xurídica e urbanística desta comunidade étnica? Ou máis ben na fundación de dúas cidades independentes no seu ámbito de asentamento? Sexa como for, unha forma alternativa do topónimo, Klaudionérion, asimilaríao máis ben aos

ciudades...”, cit., páx. 364; A. RODRÍGUEZ COLMENERO, "Integración administrativa del Noroeste peninsular en las estructuras romanas", en A. Rodríguez Colmenero (coord.), Lucus Augusti: el amanecer de una ciudad, vol. I, A Coruña, 1996; I. SASTRE PRATS, Formaciones sociales y organización territorial en el Conventus Asturum: la integración en el mundo romano y el proceso histórico durante el Alto Imperio, tese de doutoramento inédita (Universidad Complutense de Madrid), 1999, páx. 129; D. DoPICO CAínZOS, "Nuevas formas de administración, nuevas formas de control: la fundación de Lucus Augusti y su conventus", Portugalia, 34, 2013; M. FERNÁNDEZ CALO, A organización..., cit., páxs.48-49.

30 Respectivamente, CIL II, 3271 e 4616.

31 A. TRAnOY, La Galice..., cit., páx. 150; M. Fernández CAlo, A organización..., cit., páx. 43.

32 P. Le RouX, "Las ciudades...”, cit., páx. 366.

33 A. Tranoy, La Galice..., cit., páx. 199; P. LE RouX, “Las ciudades...”, cit., páx. 367; E. ORTIZ DE URBINA, Las comunidades..., cit., páx. 128.

34 Ptol., Geog., II, 6, 21.

35 Plin., Nat., IV, 111-112.

36 Ptol., Geog., II, 6, 22.

37 Itinerarium Antonini, 424, 3. 
veciños Celtici Neri ${ }^{38}$... E mesmo non tanto a Claudio coma a Nerón.

Deixando atrás estes testemuños temperáns, é realmente a familia flaviana a que abrangue un meirande número de cidades. Testemúñase un total de sete delas no noroeste da provincia Hispania citerior, o que lle outorga ao noso ámbito a meirande concentración dos mesmos: Aquae Flauiae ${ }^{39}$; Bergidum Flauium ${ }^{40}$, Flauia Lambris $^{41}$, Flauionauia $^{42}$, Flauium Brigantium ${ }^{43}$, Interamnium Flauium $^{44}$ e Iria Flauia ${ }^{45}$. Tan alta densidade e a presenza na Callaecia de varias ciuitates de Celtici ${ }^{46}$ teñen cominado ademais a sospeita de que Celticoflauia, testemuñada nunha estela lusitana ${ }^{47}$, tamén se situaría aquí ${ }^{48}$, constituíndo un oitavo exemplo. Con todo, esta cidade podería facer referencia, se cadra con meirande probabilidade, aos Celtici do Guadiana, no mesmo ámbito provincial có devandito testemuño epigráfico ${ }^{49}$.

Deste cómputo, só a referida Celticoflauia, amais de Flauia Lambris e se cadra mesmo Flauium Brigantium ${ }^{50}$, presentan dúbidas razoábeis arredor da súa localización aproximada $^{51}$. De calquera xeito, a distribución xeral destas localidades advirte claramente unha incidencia adscribíbel aos tres conuentus iuridici noroccidentais da Hispania citerior, e especialmente ás súas áreas máis subdesenvolvidas ou peor asimiladas á cultura romana, lonxe das tres capitais augusteas. Por esta razón, presúmese que detrás da súa promoción se atoparía o propósito imperial de fortalecer o artellamento urbano e a asimilación cultural da Asturia et Callaecia ${ }^{52}$.

Aquae Flauiae é, como veremos, a única destas cidades para a que existe un testemuño expreso do seu título municipal, pero dende logo os epítetos dinásticos apuntan indefectibelmente á promoción constitucional de todas elas en tempos da dinastía Flavia. Non estamos a sinalar nada novo, pois esta convicción estivo presente na historiografía canda menos dende o estudo da influencia vespasianea en Hispania de R. K. McElderry, hai exactamente un século ${ }^{53}$. Porén, o común híper-criticismo verbo á municipalización da Asturia et Callaecia converteu esta idea en case un tabú. Por exemplo, J. Santos houbo de se desdicir no seu momento da asociación intrínseca entre o epíteto flavio e o estatuto municipal, verbo ao que máis recentemente E. Ortiz de Urbina denunciou requerir de "hipóteses previas"; e nesta liña D. Fonseca Sorribas chegou a elevar á categoría de "feito" a presunción de existiren "comunidades no noroeste que levaban un nome flaviano que non foron municipia" ${ }^{\text {. }}$. En realidade, a

38 Plin., Nat., IV, 112.

39 CIL II, 2477-2478; 4204; Itin. Ant., 422, 6; Itinerario de Barro de Astorga; Hidacio de Chaves, Chronicon, 201 [196]; 207 [202].

40 Ptol., Geog., II, 6, 28; Itin. Ant., 425, 5; 429, 1; 432, 1; Ravennate, 320, 10.

41 Ptol., Geog., II, 6, 26

42 Ibíd., II, 6, 5.

43 Ibíd., II, 6, 4; Itin. Ant., 424, 5; Notitia Dignitatum, pars Occidentalis, XLII, 30.

44 Ptol., Geog., II, 6, 28; Itin. Ant., 429, 2; 432, 2; Rav., 320, 14.

45 Ptol., Geog., II, 6, 23; Rav., 321, 7.

46 Pomponio Mela, De Chorographia, III, 7-9; Plin., Nat., III, 28; IV, 112.

47 CIL II, 880.

48 J. UNTERMANN, "Anotaciones al estudio de las lenguas prerromanas del Noroeste de la Península Ibérica", en AA.VV., Galicia: da romanidade á xermanización: problemas históricos e culturais, Santiago de Compostela, 1993, páx. 385.

49 Plin., Nat., IV, 116-118.

50 R. M. FRANCO MASIDE, "La vía per loca marítima: un estudio sobre vías romanas en la mitad noroccidental de Galicia", Gallaecia, 20, 2001, páx. 226.

51 M. FERNÁNDEZ CALO, A organización..., cit., páxs. 63-65.

52 A. TRANOY, "Permanences indigenes...", cit., páx. 79.

53 R. K. MCELDERRY, "Vespasian's reconstruction of Spain”, JRS, 8, 1918, páxs. 75 e ss.

54 Respectivamente, J. SANTOS YANGUAS, Comunidades..., cit., páxs. 88-89; D. FonsECA SorRIBAS, “El 
única forma de goberno constatada para estas comunidades é precisamente o municipal, como recoñece o consenso académico actual arredor de Chaves, non existindo, se acaso - e isto discutirémolo amplamente neste traballo_, referencias unívocas para as demais comunidades.

Porén, nesta cuestión non só cómpre xogar co epíteto imperial, pois tamén consta o privilexio xurídico, sendo a orixe de todas estas cidades — ou canda menos a adición do epíteto dinástico ao seu topónimo - o período flaviano. O devandito epíteto acredita ou a súa fundación ex nihilo ou a súa promoción xurídica por parte do goberno imperial. No contexto histórico ao que se adscribe tal adición toponímica, marcado pola municipalización, esta segunda posibilidade semella dende logo máis plausíbel, e unha promoción xurídica non deixa máis solución aparente cá adopción do réxime municipal. Porén, mesmo en caso de fundacións ex nihilo, o modelo constitucional destas presuntas novas comunidades sería dificilmente disociábel ao municipal. En efecto, o que require de hipóteses previas nestas circunstancias é a presunción dun réxime non municipal para as cidades en cuestión. E entre estas hipóteses apenas podemos contar coas seguintes:

$1^{\mathrm{a}}$. - que os Flavios fundasen na Asturia et Callaecia novos núcleos peregrinos nun contexto de latinidade xurídica xeral;

$2^{\mathrm{a}}$. - que nestas promocións imperiais se potenciase o réxime «pre-municipal» ástur-galaico, baseado nas sub-unidades cívicas dos castella e gentilitates ${ }^{55}$, cando este, como veremos nun apartado específico máis adiante, estaba a ser abandonado sistematicamente polas comunidades veciñas;

$3^{\mathrm{a}}$. - que estas cidades si respostasen a un modelo institucional romano, pero non ao auto-goberno, estando ao cargo de praefecti, funcionarios delegados locais, solución que dende logo non se coñece na Asturia et Callaecia e se oporía á propia política flaviana de potenciación xeneralizada do auto-goberno local en Hispania;

$4^{\mathrm{a}}$. - que os Flavios inventasen nestas fundacións da Asturia et Callaecia un modelo constitucional absolutamente novo, que non respostase nin ao coñecido neste ámbito nin na propia lexislación romana.

Obviamente, ningunha destas posibilidades — nin sequera a última—é obxectivamente desbotábel a través da documentación histórica dispoñíbel; pero o contexto histórico si invita a desbotalas todas, e a concluír que o modelo constitucional destas fundacións ou promocións urbanas foi efectivamente o municipal que daquela se estaba a difundir por toda a península ibérica.

$\mathrm{Na}$ orixe das cidades flavianas non cómpre atender unicamente ao papel imperial, senón tamén —e se cadra fundamentalmente, se é que foron resultado de promocións e non fundacións ex nihilo-, ás súas propias dinámicas socio-políticas internas, condicionadas pola latinización xurídica. Isto corresponderíase á distribución diferencial destas cidades: as áreas máis subdesenvolvidas da Asturia et Callaecia, onde xorden, serían tamén as máis susceptíbeis a experimentaren transformacións socio-políticas radicais pola innovación xurídica, que as igualaba de súpeto a outras comunidades máis achegadas dende había tempo aos patróns culturais e estruturais «mediterráneos». Por suposto, esta lectura non exclúe o papel imperial, toda vez que efectivamente se enxerga nos propios epítetos comunitarios e no presumíbel interese de ampliar o artellamento urbano da Asturia et Callaecia a través destas promocións.

municipium...”, cit., páx. 523; E. ORTIZ DE URBINA, Las comunidades..., cit., páx. 128. Traducións do castelán orixinal.

55 Véxanse, por exemplo, Pereira Menaut, G., "Los castella...”, cit.; M. Fernández CAlo, "O desenvolvemento...”, cit., páxs. 104 e ss. 


\section{A tribo Quirina}

A cidadanía romana, fronte á latina, incluía unha serie de dereitos políticos, e entre eles o sufraxio nos comitia tributa, onde o corpo cívico era dividido nas tribos servianas. $\mathrm{O}$ Edicto de Latinidade de Vespasiano houbo de regular xa, verbo aos particulares gratificados coa cidadanía romana per honorem como consecuencia da latinidade das súas comunidades, a súa adscrición á tribo Quirina. O efecto desta disposición enxérgase na proliferación en toda a Hispania alto-romana de epígrafes con referencia a múltiples cidadáns romanos adscritos a esta tribo, claro indicativo de teren exercido eles ou os seus ascendentes- cargos civís en municipia Flauia ${ }^{56}$.

O ámbito ástur-galaico non é unha excepción, fornecendo, de feito, un significativo rexistro epigráfico desta tribo en diversas localidades e contextos sociais:

$1^{\circ}$. - Astorga: un sacerdote imperial local e dous militares lexionarios ${ }^{57}$;

$2^{\circ}$. - Braga: un militar lexionario e catro referencias de particulares ${ }^{58}$;

$3^{\circ}$. - Chaves: unha soa referencia dun particular ${ }^{59}$;

$4^{\circ}$. - León: cinco referencias de particulares ${ }^{60}$;

$5^{\circ}$. - Pinhão, Alijó: unha referencia a un militar lexionario ${ }^{61}$;

$6^{\circ}$. - Oímbra: unha referencia de incerta caracterización social ${ }^{62}$;

$7^{\circ}$. - Rosinos de Vidriales: adicación votiva dun particular a Diana ${ }^{63}$;

$8^{\circ}$. - Tarragona: seis referencias de sacerdotes imperiais ástur-galaicos, de Aquae Flauiae, Bracara Augusta, Brigiaecum, Lancia, e a ciuitas Limicorum, amais doutro de procedencia incerta dentro do conuentus bracarense ${ }^{64}$;

$9^{\circ}$. - Xinzo de Limia: epitafio dun particular ${ }^{65}$;

$10^{\circ}$. - De procedencia incerta: adicación votiva dun militar ${ }^{66}$.

A concentración destas epígrafes nas cidades de Braga e Astorga non é menos significativa do que os testemuños puntuais en contextos máis claramente rurais (véxase fig. 3). Cómpre fornecermos aquí, dun xeito seguro, as ciuitates ástures de Brigiaecum e Lancia, explicitamente mencionadas nas epígrafes de Tarragona, amais da galaicobracarense dos Limici, implicitada pola de Xinzo de Limia. Rosinos de Vidriales, pola súa banda, correspóndese ao antigo Petauonium, pólis dos Superati segundo Claudio

56 P. LE RouX, "Las ciudades...", cit., páx. 366; J. MANGAS MANJARRÉS, Aldea y ciudad en la antigüedad hispana, Madrid, 1996, páx. 61; J. ANDREU PINTADO, "Latinización...”, cit., páx. 203; íd., "Mitos...", cit., páxs. 500 e 503, nota 23.

57 CIL II, 5124; 2637; A. Rodríguez COLMENERo e S. FERrER SiERrA, "Entre Bergidum Flavium y Asturica Augusta: nuevo hallazgo epigráfico y revisión de otro ya conocido”, Larouco, 4, 2006.

58 CIL II, 2424; 2437-2438; 2444; 2450.

$59 A E 1973,302$.

60 CIL II, 2675; 2681; 5700; IRPLe, 155; 209.

61 CIL II, 6291.

62 A. Rodríguez Colmenero, Aquae Flaviae..., 1997, cit., nº 213.

63 R. Martín Valls, M. V. Romero Carnicero e S. Carretero Vaquero, "Aras votivas de Petavonium", Zephyrus, 48, 1995.

64 CIL II, 4204; 4237; 6094; 4223; 4215; $4257=$ RIT, 266; 299; 275; 287; 276; 308.

65 CIL II, 2566 = IRG IV, 118 = A. RODRÍGUEZ COLMENERO, Aquae Flaviae..., 1997, cit., nº 216.

66 CIL II, 2600; $A F, 60$. 
Ptolomeo ${ }^{67}$. Máis dúbidas ofrecen as epígrafes de Oímbra e Pinhão, cuxa localización na veciñanza flaviense podería vencellalas tanto a esta importante cidade como ás comunidades rurais veciñas. Sexa como for, en todos estes casos «rurais» a presenza de cidadáns romanos veríase igual de documentada ca en Chaves, o exemplo paradigmático da municipium Flauium na Asturia et Callaecia. Por último, en León, centro lexionario, destaca o feito de que todos os seus numerosos testemuños dispoñíbeis se correspondan a particulares, o que acreditaría a presenza ordinaria nesta localidade de cidadáns romanos alleos ao ámbito militar; e isto, asemade, apoiaría o funcionamento municipal da canaba civil deste campamento.

A distribución espacial destas epígrafes é xeneralizada, non discriminando entre ciuitates de carácter urbano e rural. O que si discrimina, pola contra, é todo o conuentus iuridicus lucense, incluída a súa capital (cfr. fig. 3). Poida que aquí o Latium minus se expresase dun xeito diferente? Contamos co testemuño africano de Lambèse-Tazoult, onde se enterrou un militar lexionario de Lugo, Reburrino Fusco, cunha adscrición cívica á tribo Galeria $^{68}$. Obviamente, Reburrino houbo de entrar no servizo lexionario pola súa condición previa de cidadán romano, o que acreditaría a presenza en Lugo, dende moito antes, dunha familia con cidadanía romana adscrita á tribo Galeria. Embora a estela de Lambèse-Tazoult semelle "pouco probatorio" arredor da constitución municipal de Lugo ${ }^{69}$, supón dende logo un indicio a prol de que a cidadanía per honorem en Lugo se expresase coa adscrición á tribo Galeria, toda vez que aquí a Quirina non se ve en absoluto representada. Tal solución non comporta ningunha anomalía, pois a constitución municipal de Lugo, coma a de Astorga e Braga — estas si adscritas, aparentemente, á tribo Quirina - , se foi anterior ao Edicto de Latinidade, houbo de se inserir nun contexto de diversidade institucional previo á uniformidade que a municipalización flaviana estendería aos novos municipia; mais non necesariamente aos que estivesen constituídos previamente.

A cuestión da cidadanía romana na Asturia et Callaecia reborda os limitados obxectivos do presente estudo. Abonde con concluírmos que dende logo se evidencia a proliferación rexional da tribo Quirina, na liña da lexislación flaviana e do contexto xeral hispano. Esta circunstancia tamén se expresa no recrutamento lexionario: seguindo as datacións consideradas por N. Santos Yanguas, antes de Vespasiano testemúñanse unicamente tres militares lexionarios galaicos; dende el e ata o remate do século II, canda menos dezanove ${ }^{70}$. Dado que os intereses militares houberon de motivaren en grande medida a concesión xurídica ${ }^{71}$, semella de todo lóxico que se procurase que a adquisición da cidadanía romana per honorem implicase tamén ás ciuitates rurais, onde sen dúbida vivía a meirande parte da poboación e probabelmente a máis susceptíbel ao recrutamento. Para isto cumpría garantir a súa implicación no exercicio de maxistraturas, xa fose nas propias ciuitates rurais ou nos centros urbanos aos que foren adscritas. Isto semella confirmado, verbo á tribo Quirina, nos conuentus iuridici asturicense e bracarense. No lucense o rexistro epigráfico non aporta nin un só testemuño, no que se cadra xogue tanto a disparidade das súas estruturas políticas como a diferente adscrición tribal nos seus municipia.

67 Ptol., Geog., II, 6, 34; véxase A. Tranoy, La Galice..., cit., páx. 51.

68 CIL VIII, 3226.

69 A. TRANOY, La Galice..., cit., páx. 203. Tradución do francés orixinal.

70 N. SANTOS YANGUAS, El ejército y la romanización de Galicia: conquista y anexión del noroeste de la Península Ibérica, Oviedo, 1988, páx. 233.

71 J. MANGAS MANJARRÉS, Aldea..., cit., páxs. 59-60. 


\section{Ordines decurionum}

A característica principal do municipium romano foi o autogoberno, representado por un órgano deliberativo local que lexislaba e escollía maxistrados. Estes órganos foron moi diversos, tanto no seu tamaño coma na súa denominación ${ }^{72}$, pero compuxeron invarialbelmente a expresión política das — tamén diversas - elites sociais locais: os ordines decurionum.

Malia a relativa pobreza do seu rexistro epigráfico, a Asturia et Callaecia reportan varios claros testemuños arredor da presenza destes ordines:

$1^{\circ}$. - Braga: estela funeraria adicada decreto decurionum a un militar lexionario ${ }^{73}$.

$2^{\circ}$. - Castro de Avelãs, Bragança: adicación do ordo Zoelarum ao deus Aernus ${ }^{74}$. Na expresión aducida non se explicita un ordo decurionum, pero si que se lle asimila claramente, canda menos dentro das posibilidades semánticas do termo no contexto específico deste testemuño ${ }^{75}$.

$3^{\circ}$. - Chaves: nunha estela votiva adicada a Iupiter Optimus Maximus, o adicante presenta a posíbel lectura $\ll o(r d o)$ municipalis ${ }^{76}$. Con todo, tal solución resulta insegura, pois sobre a potencial mención ao ordo actuou unha sensíbel erosión que ten levado noutras ocasións a ler $\ll I($ oui $)$ O(ptimo) $M\left(\right.$ aximo) municipalis ${ }^{77}$.

$4^{\circ}$. - Lugo: estela funeraria, hoxe perdida, adicada decreto decurionum pola esposa dun militar defunto ${ }^{78}$.

$5^{\circ}$. - Ponte Puñide, O Pino: moio con campo epigráfico ${ }^{79}$. É este un documento excepcional e serodio, da segunda metade do século IV, que serviu para o pago tributario dalgún municipium galaico. O seu campo epigráfico refírese aos encargados da súa facturación: Potamio et Quentiano principalibus, claramente asimilábeis aos principales Curiae ${ }^{80}$, o "comité executivo" 81 das curias, denominación baixo-romana dos órganos deliberativos municipais.

Testemúñanse así ordines decurionum en Bracara Augusta, Lucus Augusti e a ciuitas Zoelarum, e dun xeito inseguro en Aquae Flauiae. A adscrición xeográfica do moio de Ponte Puñide, pola súa banda, non é tan doada; mais segundo teño defendido noutra achega recente, o lugar de achado conforma o principal argumento do que se dispón para aproximarmos a adscrición civil deste documento, que apuntaría á ciuitas Copororum $^{82}$.

En suma, atópanse, entre senllas referencias ás principais cidades da Callaecia precisamente, aquí, Braga, Lugo e Chaves, embora esta última dun xeito incertooutras dúas vencelladas a un contexto claramente rural e politicamente secundario: a

72 J. NICOLS, “On the Standard Size of the Ordo Decurionum”, ZSSR, 105, 1988.

73 CIL II, 2424.

74 CIL II, $2606=A F, 107$.

75 E. ORTIZ DE URBINA, Las comunidades..., cit., páx. 122.

$76 A F, 4$.

77 AE 1973, 305.

78 CIL II $2582=$ IRPL $24=$ IRG II, 75.

79 CIRG I, 87.

80 R. de UreñA, "El modius de Ponte Puñide”, BRAH, 66, 1915, páx. 485-502; M. KuliKOwSKI, Late Roman Spain and its Cities, Baltimore, 2010, páx. 45.

81 L. A. CURCHIN, "The end of local magistrates in the Roman Empire”, Gerión, 32, 2014, páx. 277. Tradución do inglés orixinal.

82 M. FERnÁNDEZ CALO, “Transformacións...”, cit., páxs. 35-36. 
ciuitas Zoelarum e, probabelmente, a Copororum. Tamén diversa é a funcionalidade que se albisca para os ordines ástur-galaicos segundo a natureza dos seus testemuños: fronte ás súas funcións ordinarias - lexislaren e escolleren maxistrados - non documentadas, atópanse no noso rexistro realizando adicacións votivas en Aquae Flauiae e a ciuitas Zoelarum; decretando funerais a militares imperiais en Braga e Lugo; e implicándose na recadación fiscal, ou simplemente na revisión de pesos e medidas, no moio de Ponte Puñide.

\section{Cargos municipais}

O goberno municipal romano consistía na elección, por parte dos órganos deliberativos locais, de maxistraturas colexiadas temporais con diversas funcións. Para variar, a pobreza da epigrafía honorífica da Asturia et Callaecia motiva un rexistro fragmentario destas maxistraturas, que neste caso aparece, ademais, concentrado en Astorga:

$1^{\circ}$. - No excepcional documento denominado o «itinerario de barro» de Astorga, cuxa datación se sitúa probabelmente arredor dos séculos III e IV d.C. ${ }^{83}$, atópase a mención do duumuir Caio Lépido. Malia as dúbidas de A. García y Bellido ${ }^{84}$, se cadra cumpra atribuír esta figura municipal paradigmática á propia Astorga, localidade do achado.

$2^{\circ}$. - Nunha renovación e extensión do ano 152 d.C. do antergo pacto dos Zoelae ${ }^{85}$ cítanse como subscribintes a Lucio Domicio Silón e Flavio Severo. A súa caracterización allea aos implicados no pacto podería asimilalos a legati que actuasen como testemuñas, xa fosen por parte de Astorga, dos Zoelae, de un por cada ciuitas, ou simplemente da administración romana vencellada ao conuentus iuridicus, nun contexto análogo ao da tessera de Castromao, segundo se tratará de contado. Porén, a súa duplicidade podería identificalos tamén como duumuiri municipais, xa fosen de Astorga, onde se produciu o documento, ou da ciuitas Zoelarum á que atinxía. O feito de o pacto anterior recolleito no mesmo documento, do 27 d.C., estar subscrito por un magistratus Zoelarum favorece ao meu ver a redución na mesma ciuitas dos hipotéticos duumuiri Lucio Domicio Silón e Flavio Severo. Aquel magistratus, de feito, é sen dúbida o antecedente peregrino do duovirato municipal, ao ter sido no seu momento a maxistratura suprema da ciuitas Zoelarum $^{86}$.

$3^{\circ}$. - Testemúñanse magistri en dúas inscricións: Gaio Pacato e Flavio Próculo como intercesores dunha adicación pública a Deouagus Donnaegus ${ }^{87}$; e Aurelio Vexeto e Elio Dentón, no epitafio adicado polos magistri do seu collegium $^{88}$. Segundo M. Pastor Muñoz, esta figura do magister sería expresión dun sacerdocio municipal, o que resulta evidente canda menos no primeiro caso ${ }^{89}$. É interesante sinalar, como teño argumentado nunha achega recente, a potencial correspondencia deste magisterium cun aparente collegium funeraticium mencionado, a mediados do século III, na epístola de Cibrán de Cartago ás igrexas hispanas, que tería

83 J. M. ROLDÁN HERVÁs, Itineraria Hispana: fuentes antiguas para el estudio de las vías romanas en la Península Ibérica, Valladolid, 1975, páx. 168.

84 A. GARCÍA Y BELLIDO, "El llamado Itinerario de barro”, BRAH, 172, 1975, páx. 553.

85 CIL II, 2633.

86 M. FERNÁNDEZ CALO, “O desenvolvemento...”, cit., páxs. 114-116.

87 CIL II, $2636=$ IRPLe, 63.

88 AE 1928, $167=$ IRPLe, 99.

89 M. PASTOR MUÑOZ, "Participación indígena astur en la vida social romana”, MHA, 1, 1977, páx. 195. 
administrado os funerais dos fillos do bispo Marcial $^{90}$.

$4^{\circ}$. - Por último, se os augures compuxeron parte dos collegia sacerdotais dos municipia latinos ${ }^{91}$, cumpriría engadir aínda o augur Lucio Cosconio ${ }^{92}$, enterrado preto da cidade; cuxo epitafio, con todo, cita a súa origo como Uallatensis, o que indica que non era asturicense. Porén, ignorándose a localización desta *Uallatia, se cadra se poida manter a hipótese dun verdadeiro augur municipal, levándoo non a Astorga senón a algunha comunidade secundaria da súa contorna, que polo motivo que fose se enterrou na capital conventual.

Como se observa, o único destes testemuños cun carácter expresamente político sería o duumuir Caio Lépido, cargo «canonicamente» municipal vencellado ao goberno local. É moi salientábel o completo organigrama de maxistraturas municipais de Astorga que, nas súas implicacións máximas, ofrecerían estas epígrafes. Do mesmo xeito cumpriría valorar, na contorna inmediata de Astorga, o lictor Popilio Respecto ${ }^{93}$, que no século II d.C. erguería en León unha estela na honra da súa defunta esposa; e do que A. García y Bellido ${ }^{94}$ admitiu o seu vencello ao séquito dalgún cargo municipal da canaba civil de León, ou ben, se cadra máis plausibelmente, dalgunha alta maxistratura provincial presente neste importante centro lexionario. Sexa como for, os lictores cítanse na lei colonial de Osuna ${ }^{95}$ como parte do séquito dos duumuiri.

De calquera xeito, fóra deste «fulcro asturicense» da epigrafía institucional do noroeste da Hispania citerior atópase algún testemuño máis. Temos precisamente un caso semellante ao do lictor de León na tessera de Castromao, na que se deixou constancia dun hospitium entre a ciuitas dos Coelerni e o praefectus militar Antonio Aquilo Novaugustano no 132 d.C., sendo confirmado polo legatus Campanio Xémino96. A. Tranoy sospeitaría a súa correspondencia cun legatus iuridicus provincial ${ }^{97}$; pero unha solución igualmente admisíbel é a representación dos propios Coelerni, pois a legatura fica ben testemuñada como munus ou servizo público municipal ${ }^{98}$. O mesmo acontece co tabularius Xulio Rufino Leoncio de Lugo, obviamente encargado dun arquivo censal (tabularium) nesta localidade ${ }^{99}$. Embora G. Alföldy teña suxerido a súa plausíbel correspondencia cun órgano provincial da efémera Hispania Superior, de comezos do século III, que houbo de asentar a súa sé administrativa precisamemente en Lugo ${ }^{100}$, no presente estudo non se pode obviar a posibilidade dun cargo burocrático local, asistente

90 Cyp., Epist., LXVII, 6. A patria ástur-leonesa do bispo Marcial foi defendida por R. TEJA CASUSO, "La carta 67 de S. Cipriano a las comunidades cristianas de León-Astorga y Mérida: algunos problemas y soluciones”, Antig. crist., 7, 1990, páxs. 119-120, nunha argumentación reforzada pola correspondencia do collegium que puxen de manifesto en M. FERNÁNDEZ CALO, "Contribución de dos textos eclesiásticos tempranos para el estudio de la administración romana de la Callaecia en el siglo III", Pyrenae, 48/1, 2017, páxs. 127-123.

91 Como o foron nas colonias romanas: Lex Ursonensis, 66-67; 91. Véxanse M. PASTOR MUÑOZ, "Participación...”, cit., páx. 195; J. MANGAS MANJARRÉS, Leyes coloniales..., cit., páxs. 41-43; P. LE RouX, "Cultos y religión en el noroeste de la Península Ibérica en el alto Imperio Romano: nuevas perspectivas", Veleia, 26, 2009, páx. 227.

92 CIL II, $2647=$ IRPLe, 239.

93 IRPLe $178=A E 1967,225$.

94 A. GARCíA Y BELLIDO, "Parerga de arqueología y epigrafía hispano-romanas (iii)", AEA, 39, 1966, páx. 137.

95 Lex Ursonensis, 62.

$96 A E 1972,282=A F, 610$.

97 A. TRANOY, La Galice..., cit., páx. 383.

98 L. A. CURCHIN, “The end...”, cit., páx. 280.

99 IRG II, $29=$ IRPLu, 28.

100 G. ALFÖLDY, Provincia Hispania Superior, A Coruña, 2002, páx. 60. 
dos maxistrados municipais.

Preto de Castromao, na estela de Asadur ${ }^{101}$, probabelmente de época severiana e dende logo un dos poucos exemplos de epigrafía honorífica galaico-romana, atópase a mención de Licinio Vexeto, a quen a res publica Interamicorum honrou porque, "alén dos seus outros moitos méritos, conseguiu co seu infatigábel coidado e habilidade unhas contas xustas co Fisco" (super alia conplura merita pares cum fisco rationes infatigabili cura et industria eius consecuta). Como amosei no meu recente estudo arredor do municipium galaico baixo-romano, as solucións léxicas do texto epigráfico asimilarían este persoeiro a un curator rei publicae, cargo de notábel desenvolvemento na Baixa Romanidade, en detrimento das maxistraturas tradicionais ${ }^{102}$. Inicialmente, sobre todo dende o século II d.C., os curatores eran nomeados extraordinariamente pola autoridade imperial, constituíndo unha solución circunstancial a determinadas necesidades comunitarias $^{103}$, e especialmente, coma neste caso, a negociación das obrigas fiscais ${ }^{104}$. Máis adiante, no período baixo-romano adquirirán un rol máis estrutural, extraéndose directamente dos curiais locais e vencellándose, así, ao cursus honorum municipal, motivado fronte ás maxistraturas tradicionais polo prestixio do achegamento imperial $^{105}$. Fose cal for o transfondo institucional do curator Licinio Vexeto de Asadur, representaría "sobre todo a evolución política e urbana deses pequenos centros despois da introdución do dereito latino" 106 .

Como se amosou no caso de Astorga, os sacerdocios locais compuxeron unha parte significativa do entramado institucional dos municipia romanos. Con todo, na Asturia et Callaecia foi máis influínte o flaminado «conventual» instaurado xa en tempo de Augusto nas cidades de Astorga, Braga e Lugo ${ }^{107}$. A municipalización destas cidades houbo de vencellar o devandito sacerdocio, independentemente da súa influencia rexional e da adlectio neles de individuos de comunidades veciñas, ao entramado institucional local. O flaminado, con todo, non se ve unicamente testemuñado nestas cabeceiras conventuais, senón tamén, aparentemente, nunha moi fragmentada estela de Santa Eufemia de Ambía, Baños de Molgas ${ }^{108}$. Resulta problemática a adscrición etnopolítica desta localidade, que de certo non se correspondeu a ningunha cidade romana importante, senón a algunha comunidade de carácter rural, xa fose a dos Coelerni, Interamici ou os Limici que ocuparon as bisbarras veciñas. Alén das dificultades de lectura referentes a esta epígrafe, cómpre apuntarmos que tanto pode referenciar o cursus honorum dun particular desta área que tivese accedido ao flaminado conventual, como opina A. Rodríguez Colmenero ${ }^{109}$, coma a expresión doutro sacerdocio de proxección local. En ambos os casos, e sempre que a lectura flamini sexa atinada, testemuñaríase a fonda implicación dunha ciuitas rural galaico-bracarense nas estruturas políticas romanas, amais do seu estatuto municipal ou canda menos «adtributo» a un municipium.

\footnotetext{
$101 \quad A E 1973,317=A F, 592$.

102 M. FERNÁNDEZ CALO, "Transformacións...", cit., páx. 32.

103 L. LAMOINE, Le pouvoir..., cit., páx. 51; L. A. CURCHIN, “The end...”, cit., páx. 280.

104 M. KULIKOWSKI, Late Roman Spain..., cit., páx. 44.

105 J.-M. CARRIÉ, "Developments in provincial and local administration", CAH, XII, Cambridge, 2005, páxs. 295-296; L. A. CURCHIN, “The end...”, cit., páx. 276 e ss.

106 P. Le Roux, "Las ciudades...", cit., páx. 375. Tradución do castelán orixinal.

107 Ibíd., páx. 369-370; F. J. Lomas SALMONTE, "Consideraciones...", cit., páxs. 180-183; D. Dopico CAÍnZos, "Política imperial y romanización: el papel de Augusto en la transformación de los pueblos del NO hispánico", Gallaecia, 25, 2006, páx. 441; íd., "Nuevas formas...", cit., páx. 86.

108 IRG IV, 143.

$109 \quad A F, 359$.
} 
Porén, as mencións institucionais ástur-galaicas non se limitan á súa produción epigráfica autóctona, senón que boa parte delas procede de ben lonxe, de Tarragona, a capital provincial alto-romana, onde os municipes desta rexión aspirarían a completaren as súas carreiras político-sacerdotais. Neste senso, a rica epigrafía tarraconense aporta oito cursus honorum que, malia a distancia, se cadra compoñan as mencións institucionais máis elocuentes da municipalización da Asturia et Callaecia:

$1^{\circ}$. - Cerecio Fusco, da galaico-bracarense Aquae Flauiae, completou o cursus honorum municipal antes de acceder ao flaminado provincial ${ }^{110}$;

$2^{\circ}$. - Fabio Silón, do asturicense Brigiaecum, onde foi duumuir por dúas ocasións, antes de acceder ao flaminado conventual en Astorga e continuar a súa carreira en Roma e Tarragona ${ }^{111}$;

$3^{\circ}$. - Flavio Sabino, da galaico-bracarense ciuitas Limicorum, onde foi duumuir antes de acceder ao flaminado conventual e provincial ${ }^{112}$;

$4^{\circ}$. - Poncio Severo, de Bracara Augusta, completou o cursus municipal antes de acceder ao flaminado provincial $^{113}$;

$5^{\circ}$. - Sulpicio Nigrón, da galaico-bracarense Auobriga, nas mesmas circunstancias có anterior ${ }^{114}$;

$6^{\circ}$. - Ulpio Réburo, do conuentus iuridicus bracarense pero sen mención expresa de ciuitas, nas mesmas circunstancias cós dous anteriores ${ }^{115}$;

$7^{\circ}$. - Valerio Arabino, do asturicense Bergidum Flauium, completou o cursus municipal antes de acceder ao flaminado provincial e continuar unha carreira administrativa $^{116}$;

$8^{\circ}$. - Xunio Marón Emilio Paterno, da asturicense Lancia, completou tamén o cursus municipal, sendo duumuir por dúas ocasións antes de acceder ao flaminado conventual en Astorga e continuar logo a súa carreira en Roma e Tarragona ${ }^{117}$.

En consecuencia, testemúñanse cursus honorum municipais en Aquae Flauiae, Auobriga, Bergidum Flauium, Bracara Augusta e Lancia, e duumuiri nesta última, Brigiaecum e a ciuitas Limicorum: todas elas, agás Braga e Chaves, de carácter rural ou canda menos lonxe dunha caracterización urbana. Non ofrecen dúbidas para a súa redución xeográfica os Brigiaecini, Lancienses e Limici, correspondentes á contorna de Benavente, Villasabariego e a bisbarra da Limia respectivamente ${ }^{118}$. Os Auobrigenses sitúanse comunmente entre as ciuitates galaicas de incerta localización, embora o Padrão dos Povos de Chaves ${ }^{119}$ os adscriba aparentemente ao hinterland desta cidade. A expresión omnibus honoribus in re publica sua functus de presenza xeral nestes documentos epigráficos acredita a consumación do cursus honorum municipal, segundo se indicou en cada caso. O cursus municipal romano circunscribíase xenericamente á consumación persoal dos cargos de quaestor, aedil e duumuir ${ }^{120}$, sen que obviamente

$110 \quad$ CIL II, 4204 = RIT, 266.

$111 \quad$ CIL II, $6094=$ RIT, 275.

$112 \quad$ CIL II, $4215=$ RIT, 276.

$113 \quad$ CIL II, $4237=$ RIT, 299.

$114 \quad$ CIL II, $4247=$ RIT, 307.

$115 \quad C I L$ II, $4122=4259=$ RIT, 308 .

$116 \quad$ CIL II, $4248=$ RIT, 333.

$117 \quad$ CIL II, $4223=$ RIT, 287.

118 A. Tranoy, La Galice..., cit., páxs. 48 e 70-71.

119 CIL II, 2477.

120 L. A. CURCHIN, “The end...”, cit., páx. 476. 
sexa posíbel verificalo, dado que cada municipium podía presentar unha certa variabilidade de cargos, e na Asturia et Callaecia só se testemuña expresamente a última das maxistraturas referidas.

Cómpre xunguirmos estes cursus honorum aos cargos municipais que se veñen de expor e aos ordines decurionum tratados no anterior apartado, pois todos eles son só aspectos parciais dunha mesma realidade institucional: o municipium romano. $\mathrm{O}$ resultado, outra volta, é que as principais cidades, onde o rexistro é máis amplo, aparecen comunmente representadas en varios destes aspectos parciais; pero diversas comunidades locais aparecen, máis timidamente, nalgún deles (véxanse figs. 4 e 5). Emporiso, o valor histórico destas mencións é idéntico, pois todas elas constatan aspectos parciais do goberno municipal, de xeito que, con independencia da multiplicidade de testemuños implicados, indistintamente confirman en termos absolutos a organización municipal das comunidades en cuestión.

\section{Títulos oficiais comunitarios}

Un último indicio directo da municipalización das comunidades ástur-galaicas é a denominación oficial que estas se daban a si mesmas. Xa antes da latinización, no ámbito asturicense contamos interesantes testemuños do tránsito terminolóxico da gens á ciuitas, denominacións non contrapostas pero si vencelladas a un nidio matiz semántico que enfatizaría respectivamente o carácter étnico e o civil das comunidades implicadas ${ }^{121}$. Á altura da latinidade xurídica, o termo ciuitas semella ter desprazado case por completo á gens como denominación comunitaria. Sen ánimo de encetarmos aquí un estudo en fondura deste problema, podemos limitarnos a sinalar que entre as fontes conservadas sen dúbida destacan o «Padrão dos povos» de Chaves, con mención de dez ciuitates no ano 79, e a tabula Zoelarum de Astorga, con mención de tres gentes no $152^{122}$. Abofé, resulta moi tentador asociar as referencias de ciuitates a comunidades de forte desenvolvemento civil, municipal no contexto de latinidade; e as de gentes a outras máis ancoradas na organización étnica pre-romana. Porén, a semántica xenérica de ambos os termos impide toda asociación unívoca a un réxime constitucional concreto; e polo que ao obxecto do presente estudo importa, cómpre recoñecer que en concreto a voz ciuitas agocha, sen excluír, o estatuto municipal das comunidades implicadas $^{123}$.

Porén, logo da latinización non só perduran os usos terminolóxicos anteriores aplicados a un contexto xurídico sensibelmente diferente, senón que aparecen novos títulos constitucionais, asociados agora, fronte á semántica xenérica da ciuitas, indefectibelmente ao réxime municipal romano. As denominacións deste tipo constatadas na Asturia et Callaecia son municipium e res publica.

De entre todas as comunidades implicadas nestas denominacións, a propia Chaves (Aquae Flauiae) conforma sen dúbida o exemplo paradigmático de municipium na Asturia et Callaecia alto-romanas, e dende logo o único explícito na documentación. $\mathrm{O}$ propio título municipium consta documentalmente en tres adicacións votivas dos séculos I e II d.C. ${ }^{124}$ : unha á Concordia municipium municipii Aquiflauiensium; outra ao Iupiter Optimus Maximus municipalis, ou ben, como xa se expuxo, a Xúpiter «polo»

121 M. FERnÁNDEZ CALO, “O desenvolvemento...”, cit., páxs. 110-111.

122 Respectivamente, CIL II, 2477 e 2633.

123 Cfr. E. ORTIZ DE URBINA, Las comunidades..., cit., páx. 126.

124 D. FonsECA SORRIBAS, "El municipium...”, cit., páx. 523. 
ordo municipalis; e unha última á Tutela municipii Aquiflauiensium ${ }^{125}$. Delas, sería especialmente significativa a primeira, que mesmo podería reflectir o acto votivo

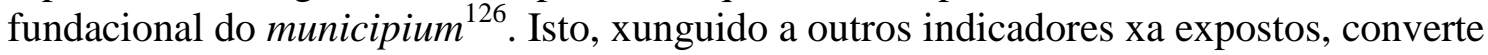
a Chaves no exemplo máis evidente de municipium Flauium da Asturia et Callaecia. Con todo, a súa denominación como ciuitas no Padrão dos Povos ten xerado algunhas opinións discordantes verbo a unha municipalización máis serodia, en tempo de Traxano (98-117), cando efectivamente se desenvolveron importantes actuacións edilicias na cidade $^{127}$. Isto incorre certamente no hiper-criticismo que comunmente arrodea o tema da muncipalización ástur-galaica, que neste caso podemos desbotar aducindo ao valor xenérico da voz ciuitas, segundo xa avanzamos.

A mención documentalmente isolada do municipium Aquiflauiensium non reflicte, de ningún xeito, a singularidade do réxime socio-político da Chaves romana na súa contorna xeográfica. Independentemente dos seus títulos constitucionais específicos, o réxime municipal, canda menos na súa acepción xenérica aquí observada, abranguiu comunidades que non se auto-denominaron municipia, ou das que non se conservou testemuño ao respecto. De feito, coa latinización xurídica de toda Hispania, os títulos colonia e municipium desdebuxaron a súa expresión socio-política orixinal, que designara o privilexio xurídico. Como consecuencia, no século II d.C. o título res publica igualaría en xeral a todas as comunidades ${ }^{128}$. Testemúñanse dúas mencións explícitas destas rei publicae galaico-asturicenses: a propia Astorga ${ }^{129}$; e unha res p(ublica) Int(eramicorum ?) citada, na xa tratada estela de Asadur ${ }^{130}$, como adicante dunha homenaxe a un posíbel maxistrado local. Semellante denominación afástase das máis primitivas gens ou ciuitas, e expresa a plena asimilación desta comunidade rural ao réxime político-administrativo romano ${ }^{131}$. Alén destas mencións, o título constitucional res publica aparece tamén nas mencións tarraconenses de cursus honorum ástur-galaicos (omnibus honoribus in re publica sua honoribus functus), o que permite sumar Aquae Flauiae, Bracara Augusta, Auobriga, Bergidum Flauium e Lancia, amais dunha ciuitas bracarense indefinida, que podería corresponderse, ou non, a algunha das anteriores ${ }^{132}$.

Esta inconcreción dos títulos constitucionais, sinónimos nun contexto de uniformidade xurídica, imposta co Edicto de Latinidade de Vespasiano (70/74 d.C.) e afianzada pola Constitutio Antoniniana de Caracalla (212), houbo de desdebuxar tamén os seus significantes. A comezos do século II, varias comunidades lusitanas veciñas da Asturia et Callaecia deixaron constancia na estela da ponte de Alcántara de teren sufragado esta obra pública ${ }^{133}$. Estas entidades, de indubidoso carácter indíxena e fortemente rurais, reciben expresamente na inscrición a denominación municipia. O certo é que un

$125 \quad A E 1973,304 ; 305 ; 2000,745=A F, 84 ; 4 ; 76$.

126 A. TRANOY, La Galice..., cit., páx. 200.

127 D. FONSECA SORRIBAS, "El municipium...”, cit., páxs. 523-524.

128 U. EsPinOSA Ruíz, Administración..., cit., páx. 28; C. WITSCHEL, "Hispania en el siglo III", en J. Andreu Pintado, J. Cabrero Piquero e I. Rodá de Llanza (coords.), Hispaniae: las provincias hispanas en el mundo romano, Tarragona, 2008, páx. 489.

129 CIL II, $2636=$ IRPLe, 63.

$130 \quad A E 1973,317=A F, 592$.

131 Cfr. A. Tranoy, La Galice..., páx. 70; A. RodríGUEZ COLMENERO, "A organización sociopolítica do espacio: etnias e territorio", en AA.VV., Galicia Castrexa e Romana: Galicia Castreña y Romana, Lugo, 1997, páx. 90; E. RIVAS QUINTAS e J. C. RIVAS FERnÁNDEZ, "El ara romana de Suatorre de Ambía (Orense) y sus inscripciones", Antig. crist., 7, 1990, páx. 576; P. LE Roux, "Las ciudades...”, cit., páx. 368.

132 CIL II 4204; 4237; 4247; 4248; 4223; 4122=RIT, 266; 299; 307; 333; 287; 308.

133 CIL II, 760. 
topónimo Municipio vai aparecer na Tardoantigüidade asociado á contorna dos Igaeditani citados na estela da Ponte de Alcántara, agora como sé episcopal de Idanha ${ }^{134}$. Estas comunidades lusitanas resultan claramente análogas ás galaicas na súa orixe indíxena e no cativo rexistro arqueolóxico da meirande parte dos seus respectivos capita ciuitatis. Se cadra non o sexan, con todo, na súa extensión, pois segundo se desprende da documentación implicada, a territorialidade política da Callaecia estivo máis fragmentada cá da Lusitania dende a Protohistoria ${ }^{135}$. Neste senso, a Callaecia semella a priori máis susceptíbel a desenvolver unha municipalización baseada na adtributio das súas pequenas comunidades arredor dos principais núcleos urbanos; namentres na Lusitania, onde aquelas abranguían espazos xurisdicionais moito máis amplos, tal solución se amosaría moito máis dificultosa, o que explicaría a municipalización directa das comunidade da ponte de Alcántara.

Cómpre ponderarmos, con todo, tales consideracións coa semántica xenérica que tería desenvolvido a voz municipium ao longo da Romanidade, por mor da uniformización xurídica e a consecuente sinonimia que terían acadado de facto os diversos títulos constitucionais. En efecto, na Romanidade terminal da Asturia et Callaecia emerxen dúas significativas mencións de municipia: Celenis e Lais $^{136}$, por cuxa datación serodia adoitan obviarse na historiografía deste tema. A mención do municipium Lais pecha, de feito, o Chronicon de Hidacio de Chaves, un dos últimos autores galaico-romanos, na segunda metade do século V. A historiografía dos dous últimos séculos non tivo reparos en asumir a pervivencia municipal neste testemuño tan explícito ${ }^{137}$, que pola súa datación serodia fuxiu do híper-criticismo que caracterizou a valoración do municipium ástur-galaico na investigación en Historia romana. Con todo, P. C. Díaz ten matizado que este municipium post-romano non podía manter as estruturas administrativas romanas, concluíndo que se denotaría "un consello de notábeis que situaban á súa fronte un persoeiro significativo no cal delegaban a representación da cidade" ${ }^{138}$. Abofé, ignórase cómo terían funcionado os municipia logo do colapso das estruturas imperiais, que na Asturia et Callaecia se produciu xa no mesmo comezo do século V, ben antes do testemuño do municipium Lais. Mais cómpre sinalarmos que, polas mesmas datas, o Breviario de Alarico II se refería ao réxime curial galo-romano baixo dominio visigodo $^{139}$; e que, como xa teño sinalado noutro lugar, a propia hipótese de P. C. Díaz debuxa unha definición dificilmente disociábel de dous elementos que caracterizaban o municipium romano: un órgano deliberativo e a elección de maxistrados ${ }^{140}$.

E como tamén sinalei daquela, “as mencións do municipium Lais, sensibelmente postromano, e Celenis, indubidosamente baixo-romano, están a reproduciren un contexto terminolóxico análogo" 141 O primeiro correspóndese ao pobo galaico-lucense dos

134 Parochiale Suevum, VII, 2; véxase M. FERnÁNDEZ CALO, "Plinio, o Parroquial...", cit., páxs. 195-196.

135 M. FERnÁndez CAlo, "Plinio, o Parroquial...”, cit., páx. 200.

136 Respectivamente, Conc. Tol. I, praefatio; Hyd., Chron., 253 [247].

137 E. PÉrez Pujol, Historia de las instituciones sociales de la España Goda, vol. II, Madrid, 1896, páx. 260; F. LóPEZ CUEVILLAS, "El municipio de Lais”, BCMO, XVIII, 2, 1955, páx. 190.

138 P. C. DíAz Martínez, "La Hispania Visigoda”, en P. C. Díaz Martínez, C. Martínez Maza e F. J. Sanz Huesma, Hispania tardoantigua y visigoda, Madrid, 2007, páx. 325. Tradución do castelán orixinal.

139 Véxase, por exemplo, C. SÁNCHEZ ALBORNOZ, Ruina y extinción del municipio romano en España e instituciones que le reemplazan, Buenos Aires, 1943, páx. 31; J. H. W. G. LIEBESCHUETZ, "Administration and Politics in the Cities of the Fifth to the mid Seventh Century", CAH, XIV, Cambridge, 2007, páx. 231.

140 M. FERnÁNDEZ CALO, “Transformacións...”, cit., páxs. 42-43.

141 Ibíd., páx. 22. 
Cileni, na contorna de Caldas de Reis. O segundo, vencellado na referencia hidaciana ao río Miño, asóciase sen dúbida ás localidades de Laias e Las, e canda elas ao antigo grande castro de San Cibrao de Las, Lansbrica. Ambos os casos remiten, xa que logo, a unha orixe inequivocamente indíxena e a un carácter fortemente rural, aínda tendo en común, probabelmente, unha significativa funcionalidade termal. Celenis e Lais redundan, en suma, na plena uniformización xurídica do réxime constitucional galaicoromano $^{142}$.

Por último, existe unha terceira denominación constitucional que acredita o desenvolvemento dun entramado institucional, se non expresamente municipal de rango, si de forma: os fora, que artellarían certas comunidades ástur-galaicas, probabelmente como consecuencia da súa reformulación constitucional — habitacional- concomitante á latinización xurídica. A denominación forum achega estes núcleos a outros exemplos do Occidente romano, creados por intervención estatal directa e bautizados comunmente conforme á dinastía en curso ou aos maxistrados implicados ${ }^{143}$. No caso galaico, o papel imperial desdebúxase pola súa denominación invariabelmente asociada a un xenitivo plural de cadansúa comunidade étnica. Testemúñanse dun xeito seguro o Forum Bibalorum ${ }^{144}$ na contorna do río Bibei ou mellor na do Búbal, onde se asentou a ecclesia tardo-antiga de Bebalos que claramente alude ao mesmo etnónimo ${ }^{145}$; o Gigurrorum en Valdeorras ${ }^{146}$; o Limicorum na Limia ${ }^{147}$; e o Narbasorum nunha localización completamente incerta ${ }^{148}$. Finalmente, especúlase un quinto forum, o Iriensium, a través da lectura hipotética de dúas estelas ${ }^{149}$.

En xeral, os fora romanos artellaron politicamente comunidades de poboamento disperso e fortemente rural $^{150}$, como semella evidente no caso ástur-galaico, onde aparecen fundamentalmente nunha área interior e carente de cidades, arredor do trifinium entre os tres conuentus (véxase fig. 6). A dimensión semántica da voz latina forum apunta primeiramente ás súas funcións mercantil e xurídica, como lugares de intercambio e realización de negocios, contratos e pactos persoais. Pero o feito de que xordan, como axiña se amosará, nun contexto de devalo dos castros, invita a considerar que ademais suplirían as súas funcións políticas e relixiosas, e que chegasen así a acumularen as funcións municipais ${ }^{151}$. De feito, consta que canda menos un dos fora galaicos, o dos Limici, se auto-organizou con maxistraturas tipicamente municipais como son os duumuiri, e que os seus cidadáns romanos se adscribiron á tribo Quirina como estipularan as leis flavianas. Isto demostra que no caso dos fora en particular son

142 Ibíd., páxs. 19-22.

143 J. MUÑIZ COELlo, El sistema fiscal en la España romana (República y Alto Imperio), Huelva, 1980, páxs. 189-190; F. PÉREZ LOSADA, "Entre a cidade e a aldea: estudio arqueohistórico dos aglomerados secundarios romanos en Galicia”, Brigantium, 13, 2002, páxs. 35-36.

144 Ptol., Geog., II, 6, 42.

145 Par. Suev., IX, 4; cfr. A. RodríGuez ColmEnero, “A organización...”, cit., páx. 89.

146 Ptol., Geog., II, 6, 37; Itin. Ant., 428, 7; Rav., 4, 45.

147 Ptol., Geog., II, 6, 43.

148 Ibíd., II, 6, 48.

$149 C I R G$ I, 12; 13. En realidade, canda menos o segundo testemuño é pura especulación, segundo teño denunciado en M. FERNÁNDEZ CALO, “O desenvolvemento...”, cit., páx. 119.

150 M. VILLANUEVA ACUÑA, "Da comunidade prerromana á galaicorromana: as fontes clásicas e a súa contribución para o problema”, en A. Rodríguez Colmenero, Los orígenes..., cit., vol. I, páx. 681.

151 G. PEREIRA MENAUT, "Un pobo e unha natio moi particulares", en G. Pereira Menaut (coord.), Galicia fai dous mil anos: o feito diferencial galego, vol. I, Santiago de Compostela, 1997, páxs. 246247; A. RODRÍGUEZ COLMENERO, "Pueblos prerromanos del convento jurídico lucense: organización sociopolítica y distribución territorial”, en A. Rodríguez Colmenero (coord.), Lucus Augusti..., cit., vol. I, páx. 151; M. VIllanUEVA ACUÑA, "Da comunidade prerromana...”, cit., páx. 681; F. PÉREZ LOSADA, "Entre a cidade...”, cit., páx. 34; M. FERNÁNDEZ CALO, A organización..., cit., páxs. 61-62. 
identificábeis "rasgos da organización municipal", independentemente do seu rango estatutivo específico ${ }^{152}$. E probabelmente cumpra admitir a título xenérico esta conclusión, coido, para o común das comunidades ástur-galaicas.

En suma, as denominacións municipium e res publica enxergan o privilexio xurídico e o auto-goberno, e xa que logo o réxime municipal romano na súa acepción xurídicoinstitucional observada no presente estudo. A mesma caracterización, no contexto da latinidade xurídica, é extrapolábel asemade aos fora e probabelmente ás xeneralidade das ciuitates locais. E malia a escaseza de testemuños, consta indefectibelmente que algunhas das principais cidades da Asturia et Callaecia, canda, outra volta, diversas entidades de carácter rural, se auto-designaron con algún destes títulos (véxase fig. 6).

\section{Indicios materiais do proceso}

A latinización xurídica vencéllase tamén á dinámica estrutural coetánea da Asturia et Callaecia, pois nas décadas contiguas detéctase un punto de inflexión nas tendencias de ocupación do territorio. En efecto, se durante a romanidade temperá, dende o século I a.C. e durante todo o período xulio-claudiano, o poboamento castrexo non se vira restrinxido, e mesmo proliferara o número de castros e estes ocuparan novas zonas ${ }^{153}$, dende o derradeiro terzo do século I d.C. vaise producir a diversificación das formas de poboamento da Callaecia; e canda ela, o progresivo abandono dos castros, incluídos os de meirande entidade ${ }^{154}$.

Os novos núcleos habitacionais foron os uici e as uillae, dos cales estas vivirían un desenvolvemento sobre todo baixo-romano ${ }^{155}$. Especialmente no caso dos uici, habitualmente houberon de supoñeren a directa substitución dos castros, e non só a nivel material. Atopamos, por exemplo, uns uicani Atucausenses, xentilicio derivado dun topónimo claramente non latino, adicando a estela de Amarante a Iupiter Optimus Maximus $^{156}$, reproducindo así unha das máis significativas competencias votivorelixiosas que tiveran os castros ${ }^{157}$. Con todo, cunhas meirandes implicacións no artellamento político da Callaecia, desenvolvéronse tamén ex novo centros habitacionais de características urbanas, os «aglomerados secundarios romanos» aos

152 C. Candelas Colodrón, Análisis de la figura de Hidacio de Chaves a través de los condicionantes socioeconómicos, políticos y culturales de la Gallaecia del siglo V: el Cronicón, tese de doutoramento inédita (Universidade da Coruña), 2004, páx. 24. Tradución do castelán orixinal.

153 Véxanse, por exemplo, C. A. F. de AlmEIDA, "O Castrejo sob o domínio romano: a sua transformação", en G. Pereira Menaut (ed.), Estudos de Cultura Castrexa e de Historia Antiga de Galicia, Santiago de Compostela, 1983, páx. 191; F. CALO LOURIDO, "A síntese: o Galaico-romano", en G. Pereira Menaut (coord.), Galicia fai dous mil anos..., cit.; T. SOEIRO, "O esplendor do Sur da Callaecia", en G. Pereira Menaut (coord.), Galicia fai dous mil anos..., cit.; G. PEREIRA MENAUT,

"Nuevas perspectivas sobre la vida en los castros galaico-romanos", Veleia, 22, 2005, páx. 121.

154 M. VILLANUEVA ACUÑA, "O Ius Latii e a transformación do hábitat galaicorromano", en AA.VV., Galicia: da romanidade..., cit.; F. CALO LOURIDO, “A síntese...”, cit., páx. 208; G. PEREIRA MEnAUt, "Un pobo...”, cit., páx. 245; T. SOEIRO, “O esplendor...”, cit., páx. 223; C. FERnÁNDEZ OCHOA, "La ciudad romana de Gijón: orígenes y dinámica histórica", en A. Rodríguez Colmenero (coord.), Los orígenes..., cit., vol. II, páx. 1115; A. M. SUÁREZ PIÑEIRO, A vida cotiá na Galicia Romana, Santiago de Compostela, 2006, páx. 81.

155 A. Tranoy, La Galice..., cit., páxs. 413-419; M. Fernández CALO, A organización..., cit., páxs. 84-85; íd., "Transformacións...", cit., páxs. 28-29.

$156 \quad$ CIL II, 6287.

157 G. Pereira Menaut, “Las comunidades...”, cit., páxs. 206-207; íd., “Un pobo...”, cit., páxs. 238240; M. FERnÁNDEZ CALO, A organización..., cit., páx. 22; íd., “O desenvolvemento...”, cit., páx. 104. 
que, para o caso galego, adicou a súa completa tese de doutoramento F. Pérez Losada ${ }^{158}$. Moitos deles houberon de seren capita ciuitatis, embora o rexistro arqueolóxico resulte normalmente pouco elocuente ao respecto. O desenvolvemento destes núcleos insírese nun proceso histórico que reborda amplamente a Callaecia: en moitos casos, a constitución de municipia Flauia incluíu o traslado in planum dos antigos oppida, agás nalgunhas excepcións nas que, probabelmente por mor de existir superficie útil dabonda, simplemente se incrementou o recinto destes núcleos en altura ${ }^{159}$. Na Callaecia o devalo dos grandes castros foi xeneralizado, coa significativa a excepción de Tongobriga, que se reconverteu nunha auténtica cidade galaico-romana ${ }^{160}$. Dun xeito especialmente evidente, os fora ástur-galaicos, xa referidos con anterioridade, ilustran os devanditos traslados in planum da poboación castrexa e o interese de artellar politicamente unhas comunidades redefinidas a nivel constitucional.

Obviamente, nun contexto no que os núcleos habitacionais anteriores, os castros, se vencellaban manifestamente á organización socio-política, estas mudanzas rebordaron o ámbito do estritamente material. Neste senso, non é casual que as mencións epigráficas a castella, directamente ou por medio do signo $\mathcal{O}$, desaparezan por completo no século II. O devalo dos castros e a disolución dos castella epigráficos conforman procesos paralelos, que se engaden a un aspecto se cadra máis significativo desta evolución histórica: a desaparición da propia institución xurídico-política á que se vencellaban ${ }^{161}$. Tense sinalado que esta desaparición sería efecto da adtributio das antergas entidades castrexas en comunidades «municipalizadas» ${ }^{162}$; pero semellante lectura agocha parte do contido substancial destas mudanzas: os castros non foran nunca entidades plenamente independentes, senón que se adscribiran a determinadas comunidades etnopolíticas. Son estas as que se «municipalizan», constituíndose en entidades unificadas, deixando atrás o paradigma castrexo do «pobo-confederación» ${ }^{163}$, independentemente de que se cadra moitas delas nin sequera adoptasen un réxime municipal propio, senón que se adscribiron a outros municipia nos que se expresaron politicamente.

Non é doado atoparmos paralelos deste proceso fóra da Callaecia, toda vez que os unidades supra-familiares celtibéricas, cuxas mencións epigráficas perduran ata o século IV, non tiveron unha dimensión territorial senón familiar ${ }^{164}$; e os pagi gálicos, efectivamente unha entidade territorial sub-local, si se integraron no entramado municipal da Galia romana e continuaron unha longa evolución posterior ${ }^{165}$. Na epigrafía da Asturia transmontana tamén semellan ter perdurado moito as referencias a gentes, nun senso aparentemente cinguido a unidades supra-familiares, inferiores ás comunidades etno-políticas locais equivalentes á ciuitas $^{166}$. Por esta razón, o castellum galaico semella atopar o seu paralelo máis acaído, malia a distancia, na Tracia romana, onde o desaparición nas mencións de origo das tradicionais stratégíai sub-cívicas se produciu ao longo do século II d.C., nun contexto de urbanización e xa que logo, coma

\footnotetext{
158 F. PÉREZ LOSADA, "Entre a cidade...", cit.

159 J. ANDREU PINTADO, "Latinización...”, cit., páx. 205.

160 L. A. T. DiAs, "Tongobriga", cit., páx. 767.

161 G. PEREIRA MenaUt, "Los castella...”, cit., páx. 261; M. Fernández CAlo, A organización..., cit., páx. 60.

162 J. ANDREU PINTADO, “Latinización...”, cit., páx. 207.

163 G. PEREIRA MENAUT, “Los castella...”, cit., páx. 264.

164 M. SALINAS DE FríAS, Conquista y romanización de Celtiberia, Salamanca, 1986, páx. 207.

165 L. LAMOINE, Le pouvoir..., cit., páxs. 13-14; M. TARPIN, "Organisation politique et administrative des cités d'Europe occidentale sous l'Empire”, Pallas, 80, 2009.

166 Como ilustran os exemplos de Morcín e Parres: CIL II, 2698; 2707; 5736; 5749 = ERA, 24; 33; $35-36$.
} 
o caso galaico, de centralización política ${ }^{167}$.

En suma, as fondas transformacións percibidas no rexistro arqueolóxico - e moi especialmente no epigráfico, coa desaparición das mencións a castella - indican mudanzas substanciais no entramado institucional galaico: nomeadamente, a reformulación constitucional das comunidades locais. Neste tempo as comunidades galaicas afirmábanse fronte aos suxeitos previamente autónomos, os castros, e producíase o nacemento de novos núcleos que a cotío servirían, probabelmente, de capita ciuitatis. Esta dinámica, abofé, non pode ser disociada da latinización xurídica e a municipalización que simultaneamente se estaba a producir polas mesmas datas.

\section{INTERPRETACIÓN}

O rexistro documental da Asturia et Callaecia resulta a todas luces moi fragmentario e rara vez aporta, verbo á municipalización, datos complementarios referentes a unha mesma comunidade, agás para as principais cidades. Mais non meramente a intuición, senón a evidencia empírica, suxire que tales probas isoladas de municipalización poden inferir por si soas o estatuto municipal das súas comunidades: como ten sinalado D. Martino García, nunca "se deu ningún exemplo de que novas inscricións refutasen a proposta de condición municipal apoiada [previamente] nun testemuño seguro"168. Emporiso, a identificación do proceso de municipalización a través da valoración isolada de cada ciuitas devén nunha solución parcial; como parcial é o rexistro, pois na meirande parte dos casos non é posíbel fornecer datos positivos, senón constatar a carencia dos mesmos. A resolución alternativa aquí desenvolvida arrombou este mesmo rexistro en varias categorías temáticas: epítetos imperiais comunitarios, presenza da tribo Quirina, documentación de ordines decurionum e maxistraturas municipais, e denominación oficial das comunidades. O resultado xeral é que, efectivamente, as principais cidades ástur-galaicas de fundación imperial aparecen sempre coma as protagonistas da documentación epigráfica; pero sempre, sen que exista unha soa categoría que o contradiga, estas son acompañadas por pequenas entidades rurais indíxenas.

Independentemente do estatuto constitucional concreto, os devanditos testemuños refírense invariabelmente ao funcionamento municipal das comunidades implicadas, canda menos na definición «xenérica» deste réxime político, segundo se desenvolveu no seu momento: lei romana e institucións romanas. Con todo, estes testemuños tamén teñen un valor diverso. Así, comunmente a historiografía matiza a influencia dos epítetos imperiais como proba do réxime municipal das comunidades implicadas. A adscrición dun particular á tribo Quirina, pola súa banda, pode sempre deberse, entroutras solucións, á adquisición da cidadanía per honorem nun municipium «adtributo», e non necesariamente ao estatuto municipal da comunidade de orixe. Porén, noutros casos os testemuños epigráficos ofrecen garantías inequívocas de municipalización nas comunidades implicadas: a presenza dun ordo decurionum propio, a constatación de cursus honorum e cargos especificamente municipais, amais da denominación municipium, obstan toda hipótese de municipalización «adtributa»e

167 Cfr. M. SARTRE, El oriente romano: provincias y sociedades provinciales del Mediterráneo provincial de Augusto a los Severos (31 a. de C.-256 d. de C.), Madrid, 1994, páx. 258.

168 D. MARTINO GARCÍA, Las ciudades romanas de la meseta norte de la península ibérica: identificación, estatuto jurídico y oligarquías (ss. I-III d.C.), tese de doutoromento inédita (Universidad Complutense de Madrid), 2004, páx. 126. Tradución do castelán orixinal. 
comportan indefectibelmente o funcionamento do réxime municipal. Só estes testemuños seguros —embora sempre susceptíbeis á súa matización puntual— se refiren a un conxunto significativo de entidades ástur-galaicas con institucións ou títulos constitucionais «municipais», e xa que logo de réxime que cómpre concibir, xa definitivamente, municipal: Aquae Flauiae, Asturica Augusta, Auobriga, Bergidum Flauium, Bracara Augusta, Brigiaecum, municipium Celenis, ciuitas Interamicorum, municipium Lais, Lancia, ciuitas Limicorum, Lucus Augusti, ciuitas Zoelarum. A isto cumpriría sumar a incerta ciuitas implicada polo moio de Ponte Puñide, se cadra a dos Copori; amais da incerta patria de Ulpio Réburo, a non ser que esta se correspondese con algunha das anteriores. Só este cómputo «mínimo» implicaría un total de quince entidades ástur-galaicas, algo máis dunha quinta parte das sesenta e dúas existentes, segundo Plinio, no século I d.C. ${ }^{169}$

Porén, ao cómputo aludido cumpriría sumar aínda outras 7 comunidades que tiveron epítetos imperiais —ou ata 8, se é que Celticoflauia foi galaica-; os canda menos 4 fora constatados; e diversas posibilidades parciais verbo á interpretación do rexistro: que o lictor de León, o legatus de Castromao e o tabularius de Lugo se vencellasen a senllos cargos municipais, que o augur Uallatensis de Astorga se puidera reducir a outra comunidade ástur-galaica, ou mesmo que cada referencia á tribo Quirina se puidese asociar ao desenvolvemento municipal específico nas comunidades implicadas. Se ás probas da municipalización se suman estes indicios, obtense que o rexistro implicado se concentra nas principais cidades, pero abrangue, en termos xeográficos, a totalidade da Asturia et Callaecia (véxase fig. 7).

Aínda eludindo estes indicios posíbeis, cómpre salientarmos que as ata 15 entidades constatadas expresamente como municipia ou con institucións asimilábeis ás municipais foron maioritariamente de carácter rural: 4 centros urbanos de primeira orde fronte a 11 comunidades secundarias. En termos estruturais —isto é, no referente ás súas estruturas sociais, urbanas, culturais - estas 11 entidades non diferían substancialmente do case medio cento de ciuitates ástur-galaicas rurais e secundarias sen probas inequívocas do seu estatuto constitucional ou sen documentación en absoluto. En efecto, o réxime municipal constátase dun xeito seguro só nunha proporción relativamente cativa: como avanzamos antes, a quinta parte das comunidades ástur-galaicas. Emporiso, existe outra posíbel lectura deste mesmo feito: a completa totalidade da documentación institucional dispoñíbel na Asturia et Callaecia post-flavianas se refire ao réxime municipal. A única excepción emerxe cos moi localizados testemuños «étnicos» de gentes, non necesariamente incompatíbeis co municipium, como amosamos a propósito da tabula Zoelarum. Sexa como for, máis do que obstarmos ex silentio o réxime municipal das entidades non constatadas, cumpriría valorar o paralelismo que as ciuitates rurais efectivamente «municipalizadas» aportan para o recoñecemento do réxime político das que non conservaron documentación.

A implantación municipal na Asturia et Callaecia respostou, coma en todos os ámbitos coñecidos, a uns condicionantes estruturais autóctonos. No ámbito bético falouse de «adaptación»; na Galia de «diálogo» entre o substrato indíxena e o modelo municipal ${ }^{170}$. Na Asturia et Callaecia preséntasenos un fenómeno análogo, no que as ciuitates eran máis pequenas do que as galas, máis rurais do que as béticas, pero no que se viron

169 Plin., Nat., III, 28.

170 Respectivamente, S. KEAY, "Towns and Cultural Change in Iberia between Caesar and the Flavians", en L. Hernández Guerra, L. Sagredo San Eustaquio e J. M. Solana Sainz (eds.), La Península Ibérica hace 2000 años: actas del I Congreso internacional de historia antigua, Valladolid, 2001, páx. 115; L. LAMOINE, Le pouvoir..., cit., páx. 58. 
indistitamente afectadas pola adaptación dun modelo constitucional exóxeno ás estruturas socio-políticas autóctonas. A urbanización ou o epigraphic habit, tan pobres na Asturia et Callaecia, son só efectos colaterais deste proceso. A transformación constitucional e a asimilación socio-cultural das elites municipais son os seus efectos directos, e isto si que se nos demostra indefectibelmente constatado.

\section{Diverxencias intra-rexionais}

De calquera xeito, a distribución espacial das institucións municipais (véxase fig. 5), denominacións constitucionais (fig. 6) e outros indicadores de potencial municipalización (fig. 7), malia cubrir en esencia a totalidade do espazo estudado, demóstrase sensibelmente irregular, o que abre certas dúbidas susceptíbeis á discusión académica. Segundo xa se avanzou, as principais cidades ástur-galaicas aparecen loxicamente sobrerrepresentadas en todas as categorías. A excepción é Lugo, cun rexistro, embora salientábel no seu conuentus iuridicus, relativamente débil; e inferior mesmo ao de comunidades ástures secundarias coma Lancia ou León. As significativas concentracións da porción mesetaria do conuentus asturicense, en relación tanto co conuentus lucense como coa propia Asturia transmontana, acreditan a súa meirande adaptación ao modelo municipal «canónico» romano, sen dúbida condicionado por unha asimilación análoga das propias estruturas socio-económicas «mediterráneas» nas que descansou a civilización romana.

En xeral, o conuentus lucense amosa un rexistro ineludibelmente máis fraco có dos dous veciños. Isto débese primeiramente á ausencia aquí de toda referencia á tribo Quirina (véxase fig. 3), probabelmente motivada non polo desbotábel estatuto peregrino das súas comunidades, senón, alén da menor asimilación cultural, por unha adscrición tribal diferente entre os cidadáns romanos deste conuentus. Na propia Lugo a tribo non está representada, o que atoparía unha doada explicación no seu hipotético estatuto latino previo e xa que logo desvencellado da lex Flauia municipalis. Derivarían da constitución municipal luguesa as ciuitates veciñas e por iso non se representa a tribo Quirina? O certo é que a distribución dos testemuños desta tribo na Asturia et Callaecia resulta, agás no caso de Chaves, oposto á senlla distribución dos topónimos flavianos, tanto no conuentus lucense coma no asturicense (cfr. figs. 2 e 3). Esta distribución diferencial podería indicar que as cidades flavianas derivasen dun proceso de promoción imperial específico dalgún xeito independente á latinización xurídica xeral. Se cadra estas promocións expresamente imperiais se asociasen non á lex Flauia municipalis senón a outras leis promulgadas ex professo, materializando doutro xeito a adscrición tribal da cidadanía romana ex uirtute... ou non materializándoa en absoluto.

Importa constatar que as áreas que aparecen máis baleiras na nosa cartografía, a Asturia transmontana e o conuentus lucense en xeral, coinciden, no primeiro caso, co amplo testemuño post-flaviano de unidades supra-familiares indíxenas ${ }^{171}$, e nos dous indistintamente coa dilatada remanencia das súas estruturas étnicas ata ben avanzada Tardoantigüidade ${ }^{172}$. Isto favorece dalgún xeito a idea dunha municipalización parcial

171 Como xa no seu momento puxo de manifesto J. SANTOS YANGUAS, Comunidades..., cit., páx. 87.

172 Segundo a interpretación usual dos etnónimos do Parroquial Suevo: véxase, por exemplo, P. C. DÍAZ MARTíNEZ, "El Parrochiale Suevum: organización eclesiástica, poder político y poblamiento en la Gallaecia Tardoantigua”, en J. Alvar (ed.), Homenaje a José María Blázquez, vol. VI, Sevilla, 1998, páx. 44. Arredor da faixa cantábrica, na que se inclúe en meirande medida a Asturia transmontana, véxase A. BARBERO e M. VIGIL, "Sobre los orígenes sociales de la reconquista: cántabros y vascones 
destas áreas periféricas da Asturia et Callaecia, que non terían chegado a desenvolveren un artellamento civil significativo máis ca en certos núcleos, sen que isto obste a integración no réxime municipal a través, precisamente, das relacións de adtributio cos núcleos municipais.

Pola súa banda, no conuentus bracarense aparece outro trazo característico da distribución documental, definido por varias circunstancias específicas (cfr. fig. 7):

$1^{\mathrm{a}}$. - a enorme concentración, a meirande da Asturia et Callaecia, de testemuños na cidade de Braga, fronte á total ausencia dos mesmos na súa contorna, a metade occidental marítima do conuentus;

$2^{a}$. - unha segunda concentración en Chaves, fronte á relativa ausencia do sudeste interior do conuentus;

$3^{\text {a }}$. - a ampla pero difuminada presenza de testemuños no nordés interior do conuentus.

Semellantes contrastes poderíanse explicar pola irregularidade do proceso de municipalización neste conuentus. Poida que Braga e Chaves, cidades de primeira orde, artellasen dende moi cedo, por medio da adtributio institucional, ás ciuitates secundarias de cadanseu hinterland. A porción nordoriental do conuentus, se cadra máis refractario a tales innovacións, e dende logo máis afastado destes dous centros urbanos, desenvolveu en troques a municipalización directa, pero probabelmente tamén máis gradual, das súas ciuitates. Hipoteticamente, isto explicaría a concentración de testemuños en Braga e Chaves, a ausencia deles nas súas respectivas contornas, e a proliferación destes no extremo nordoriental do conuentus.

Finalmente, a dinámica evolutiva da contorna inmediata de Braga amosaría un paralelismo histórico ineludíbel coa Gallia Narbonensis, onde o desenvolvemento urbano e institucional derivaría primeiramente na promoción xurídica de 75 oppida Latina, sendo posteriormente 43 deles adscritos en réxime de adtributio a uns poucos centros municipais ${ }^{173}$. Asimilaranse a este exemplo os grandes castros galaicobracarenses, sitos precisamente no «baleiro» occidente marítimo bracarense? Non se pretende desenvolver aquí esta cuestión, tan suxestiva como lonxe dos obxectivos específicos do presente estudo; pero dende logo o devalo urbanístico post-latinización destes centros é un feito constatado arqueoloxicamente, e a súa adscrición «adtributa»a Braga como forma de satisfacer os seus dereitos e obrigas derivadas da innovación xurídica debúxase como unha solución natural ás características específicas da distribución dos testemuños municipais da súa contorna.

\section{O carácter gradual do proceso}

Sería probabelmente un erro asumirmos en termos absolutos as implicacións heurísticas do rexistro histórico aquí manexado. $\mathrm{Na}$ distribución dos testemuños, case exclusivamente epigráficos, xoga sen dúbida a aculturación e a susceptibilidade das comunidades ástur-galaicas para a asimilación das estruturas socio-políticas romanas. $\mathrm{Na}$ epigrafía hispano-romana —e se cadra dun xeito máis acentuado na Asturia et Callaecia, onde esta fora sempre máis pobre - as mencións institucionais, vencelladas

desde fies del Imperio Romano hasta la invasión musulmana", en A. Barbero e M. Vigil, Sobre los orígenes sociales de la Reconquista, Barcelona, 1984.

173 C. GodineAU, "Gaul”, CAH, X, 1996, Cambridge, páxs. 474-475. 
ao epigraphic habit propio da vida civil dos municipia, dilúense dende remates do século II d.C., esvaecendo case completamente no século seguinte ${ }^{174}$. Nestas circunstancias globais, evidénciase que a epigrafía municipal ástur-galaica tivo un desenvolvemento cronoloxicamente efémero. Resulta moi significativo que, segundo se expuxo no seu momento, algunhas das mencións institucionais máis valiosas nin sequera procedan da epigrafía local, senón da de Tarragona, onde moitos maxistrados e sacerdotes ástur-galaicos concluíron as súas carreiras públicas. Por outra banda, a estela de Asadur ${ }^{175}$ constitúe unha das máis elocuentes mencións locais, destacando pola súa procedencia rural e o seu contexto presumibelmente severiano... Precisamente, a época na que xeneralizadamente estaba a decaer en toda a Península Ibérica a produción deste tipo de documentos. Non se pretende desenvolver aquí unha valoración da excepcionalidade temática e cronolóxica desta epígrafe, que se cadra se vencelle ao desequilibrio estrutural entre a Hispania «mediterránea» e as ciuitates rurais da Asturia et Callaecia, onde o epigraphic habit municipal tivo un desenvolvemento moito máis serodio; e xa que logo puido ter adiado, tamén, a súa desaparición definitiva. A razón de aducirmos isto agora, pola contra, é por ilustrar a arbitrariedade do rexistro epigráfico, e o carácter excepcional de cada un dos documentos conservados.

Nestas circunstancias, as interpretacións «pesimistas» da municipalización ástur-galaica non poden ser argumentadas ex silentio na pobreza do rexistro, pois o municipium é primeiramente un modelo constitucional, non un modo de vida urbano ou unha práctica política definida polo epigraphic habit romano. Porén, esta arbitrariedade do rexistro afecta tamén a toda interpretación «optimista». Se na Asturia et Callaecia o desenvolvemento da epigrafía institucional tivo algún paralelismo co modelo xeral aducido para a Península Ibérica, deduciríase que o rexistro documental da municipalización deste ámbito se limitaría fundamentalmente ao século II d.C.; norma que dende logo semella confirmarse, en liñas xerais, pola cronoloxía segura ou aproximativa da meirande parte das epígrafes manexadas. Mais tal acotación comporta unha porción ínfima da presumíbel vixencia histórica do municipium ástur-galaico, que cumpriría adscribir, canda menos, ao lapso que resta entre o Edicto de Latinidade (70/74 d.C.) e o remate do dominio romano $(409 / 411)^{176}$.

O amplo rexistro epigráfico alto-romano constituíu a base case exclusiva do presente estudo, embora entre algunhas fontes serodias se atopen varios dos testemuños máis valiosos manexados. Do mesmo xeito, a distribución documental tamén amosa un claro sesgo alto-romano, de xeito que as percepcións específicas dela substraídas han de seren adscritas fundamentalmente a este período temperán. Neste senso, a fonda asimilación cultural romana da área mesetaria ástur, a contraposición entre os ámbitos de distribución das cidades flavianas e a prevalencia da tribo Quirina, ou a adtributio municipal das comunidades da contorna de Braga, constitúen hipóteses que explican a devandita distribución do rexistro, e como tal afectan fundamentalmente ao período alto-romano do que este procede fundamentalmente. En troques, as referencias serodias, e moi especialmente a dimensión xenérica que tería adquirido o termo municipium no período baixo-romano, enxergan probabelmente unha meirande uniformidade políticoadministrativa de todas as comunidades ástur-galaicas, na que se terían diluído as diferenzas efectivas entre os rangos constitucionais diferenciados, especialmente

174 C. WiTSCHEL, “Hispania...”, cit., páxs. 475-476; M. KULIKOWSKI, Late Roman Spain..., cit., páx. 50.

$175 \quad A E 1973,317=A F, 592$

176 E de feito semella ter sobrevivido moito alén da implantación sueva, segundo teño argumentado con detemento en M. FERNÁNDEZ CALO, "Transformacións...", cit. 
despois da Constitutio Antoniniana do 212 que universalizou a cidadanía romana.

Neste senso, a municipalización concíbese como unha longa fase dun proceso máis amplo de mutación constitucional na Asturia et Callaecia, que tería incidido dende moito antes do Edicto de Latinidade, coa adopción por parte das comunidades etnopolíticas locais de institucións de carácter xenericamente republicano; só máis tarde «romanizadas» coa xeneralización do réxime municipal. É certo que as institucións e mesmo a autonomía local da Hispania romana distaban de conformaren, á altura do século II d.C., un panorama homoxéneo ${ }^{177}$, pero dende logo o municipium, cuxo lapso rebordou o período alto-imperial, había de uniformar máis do que nunca antes -e despois - o réxime socio-político das comunidades locais hispanas, tanto entre elas coma con todo o Occidente mediterráneo do seu tempo, e dende logo coas da Asturia et Callaecia. A dinastía Flavia abriu este fulcral chanzo do proceso, pois o Edicto de Latinidade houbo de darlle ás tímidas mudanzas anteriores un carácter sistemático e xa univocamente vencellado á influencia xurídica, legal e cultural expresamente romana. Porén, nin os Flavios nin o Alto Imperio pecharon este proceso: o municipium ásturgalaico continuou a súa evolución nos séculos subseguintes; evolución para a que existen poucas fontes pero que probabelmente se adscribiu a un contexto de meirande asimilación dos ritmos estruturais globais romanos. Mais, obviamente, cada comunidade respostou a unha dinámica propia: como atinadamente sentenciou $\mathrm{G}$. Pereira Menaut, aínda contrario, como vimos, a falar de municipium, "se Malaca e Salpensa precisaron duns dez anos para se reorganizaren, as comunidades do noroeste poden ter precisado de moito máis, e non todas o mesmo" $" 178$.

\section{CONCLUSIÓNS}

No presente estudo definiuse un concepto «xenérico» do municipium romano, ao que se asociou, con propósito de exhaustividade, unha longa serie de testemuños documentais da Asturia et Callaecia. Estes testemuños permiten identificar unha «fase municipal» na historia institucional desta rexión, incardinada nun contexto hispano e mesmo «circunmediterráneo» máis amplo. A municipalización concíbese esencialmente como un proceso de mutación constitucional das comunidades locais, nidiamente singularizado como tal; pero vencellado con todo a unha longa evolución histórica das estruturas socio-políticas locais. Contra as posturas «restritivas», que protagonizaron por moito tempo a valoración historiográfica deste proceso na Asturia et Callaecia, aquí identificouse claramente a súa incidencia «xeral», pero tamén «irregular» e «gradual». Nos devanditos caracteres é como, en síntese e ao abeiro do rexistro documental traballado, cómpre concibir a municipalización ástur-galaica:

$1^{\circ}$. - Unha municipalización xeral. Os testemuños vencellados á municipalización da Asturia et Callaecia concéntranse claramente nas principais cidades, pero amosan unha difusión xeral en todo o territorio. Constátanse máis municipia «rurais» do que urbanos. Na Callaecia, a municipalización coincide coa disolución xeneralizada do modelo constitucional «castrexo». O mesmo título constitucional municipium

177 E. ORTIZ DE URBINA, Las comunidades..., cit., páx. 177.

178 G. PEREIRA MENAUT, “Los castella...”, cit., páx. 264. Tradución do castelán orixinal. Obviamente, o citado historiador referiuse aquí á datación domicianea das leis municipais conservadas destas comunidades béticas. Hei de sinalar, con todo, que tamén isto se matiza hoxe: para J. ANDREU PINTADO, "Latinización...", cit., páx. 199, o goberno imperial de tempos de Domiciano limitaríase a publicitar as leis xa promulgadas por Vespasiano. 
adquiriu un significado xenérico e aplicado a comunidades non urbanas no período baixo-romano.

$2^{\circ}$. - Unha municipalización irregular. Advírtense diferenzas significativas entre os testemuños vencellados á municipalización en cada conuentus iuridicus, e mesmo a nivel intra-conventual. $\mathrm{O}$ ámbito mesetario ástur contrasta coa Asturia transmontana. A distribución da tribo Quirina é oposta á das cidades flavianas, o que comina o recoñecemento destas como parte dun proceso de promoción imperial específico en certa medida independente da latinización xurídica global. A concentración de referencias en Braga fronte á difusión na porción nordoriental do seu conuentus suxire a incidencia dunha municipalización adtributa da contorna da capital fronte a unha directa das comunidades do nordés bracarense.

$3^{\circ}$. - Unha municipalización gradual. O municipium foi adaptado polas comunidades ástur-galaicas dende o Edicto de Latinidade, nun proceso que probabelmente se prolongou ao século II d.C. e continuou ulteriormente a súa evolución, confluíndo cos ritmos históricos xerais deste réxime e probabelmente matizando tamén co tempo as súas propias irregularidades internas.

\section{BIBLIOGRAFÍA}

AlföLDY, G., "Spain", en A. K. Bowman, P. Garnsey e D. Rathbone (eds.), The Cambridge Ancient History, vol. XI, Cambrigde, Cambridge University Press, 2000, páxs. 444-461.

—, Provincia Hispania Superior, A Coruña, 2002.

AlmeidA, C. A. F., "O Castrejo sob o domínio romano: a sua transformação", en G. Pereira Menaut (ed.), Estudos de Cultura Castrexa e de Historia Antiga de Galicia, Santiago de Compostela, 1983, páxs. 187-198.

ANDREU PINTADO, J. "Latinización y municipalización en el Alto Imperio: nuevas perspectivas para el estudio de la Hispania de los flavios", en F. Beltrán Lloris (ed.), Antiqua Iuniora: en torno al Mediterráneo en la Antigüedad, Zaragoza, 2004, páxs. 189-210.

—, Edictum, municipium y lex: Hispania en época Flavia (69-96 d. C.), Tudela, 2004.

—, "Mitos y realidades sobre la municipalización flavia en Lusitania", en J.-G. Gorges, J. d'Encarnação, T. Nogales Basarrate, A. Carvalho (coords.), Lusitânia romana: entre o mito e a realidade, Cascais, 2009, páxs. 495-514.

BARBERO, A. e VigiL, M., "Sobre los orígenes sociales de la reconquista: cántabros y vascones desde fies del Imperio Romano hasta la invasión musulmana", en A. Barbero e M. Vigil, Sobre los orígenes sociales de la Reconquista, Barcelona, 1984, páxs. 11-104.

Bravo Bosch, M. J., "Latium maius versus Latium minus en la Hispania flavia", Anuario da Facultade de Dereito da Universidade da Coruña, 13, 2009, páxs. 39-56.

CAlo Lourido, F. "A síntese: o Galaico-romano", en G. Pereira Menaut (coord.), Galicia fai dous mil anos: o feito diferencial galego, vol. I, Santiago de Compostela, 1997, páxs. 193-212.

Candelas Colodrón, C., Análisis de la figura de Hidacio de Chaves a través de los condicionantes socioeconómicos, políticos y culturales de la Gallaecia del siglo V: el 
Cronicón, tese de doutoramento inédita (Universidade da Coruña), 2004.

CARriÉ, J.-M., "Developments in provincial and local administration", en A. K. Bowman, P. Garnsey e A. Cameron (eds.), The Cambridge Ancient History, t. XII, Cambridge, 2005, páxs. 269-312.

Cornell, T. J., "Rome and Latium to 390 B.C.", en F. W. Walbank, A. E. Astin, M. W. Frederiksen e R. M. Ogilvie (eds.), The Cambridge Ancient History, t. VII, $2^{\mathrm{a}}$ parte, Cambridge, 1989, páxs. 243-308.

Curchin, L. A., "The end of local magistrates in the Roman Empire", Gerión, 32, 2014, páxs. 271-287.

DiAs, L. A. T., “Tongobriga”, en A. Rodríguez Colmenero (coord.), Los orígenes de la ciudad en el noroeste hispánico, vol. II, Lugo, 1998, páxs. 751-778.

DíAZ MARTíNEZ, P. C., "El Parrochiale Suevum: organización eclesiástica, poder político y poblamiento en la Gallaecia Tardoantigua", en J. Alvar (ed.), Homenaje a José María Blázquez, vol. VI, Sevilla, 1998, páx. 44.

—, "La Hispania Visigoda", en P. C. Díaz Martínez, C. Martínez Maza e F. J. Sanz Huesma, Hispania tardoantigua y visigoda, Madrid, 2007, páxs. 259-611.

Dopico CAÍnzos, D., "Política imperial y romanización: el papel de Augusto en la transformación de los pueblos del NO hispánico”, Gallaecia, 25, 2006, páxs. 427-443.

—, "Nuevas formas de administración, nuevas formas de control: la fundación de Lucus Augusti y su conventus", Portugalia, 34, 2013, páxs. 83-100.

ESPINOSA RUíz, U., Administración y control del territorio en el Imperio Romano: una aproximación histórica, Logroño, 2006.

FERNÁNDEZ CALO, M., A organización político-administrativa de Galicia na Antigüidade (séculos II a.C.-VIII d.C.), tese de licenciatura inédita (Universidade de Santiago de Compostela), 2015.

-, "Plinio, o Parroquial Suevo, e a evolución estrutural do poder local galaico na Antigüidade", Gallaecia, 34, 2015, páxs. 175-207.

—, "O desenvolvemento político pre-municipal dos pobos galaicos", Gallaecia, 35, 2016.

-, "Contribución de dos textos eclesiásticos tempranos para el estudio de la administración romana de la Callaecia en el siglo III”, Pyrenae, 2017, 48/1, páxs. 115136.

—, "Transformacións e permanencia do municipium na Gallaecia barixo-romana (séculos III-V)", Cuadernos de Estudios Gallegos, LXIV, 130, 2017, páxs. 15-48.

FERNÁNDEZ OCHOA, C., "La ciudad romana de Gijón: orígenes y dinámica histórica", en A. Rodríguez Colmenero (coord.), Los orígenes de la ciudad en el noroeste hispánico, vol. II, Lugo, 1998, páxs. 1109-1124.

FonseCA SorRIBAS, D., "El municipium romano de Aquae Flaviae y su problemática", Anesteria, 1, 2012, páxs. 519-528.

FRANCO MASIDE, R. M., "La vía per loca marítima: un estudio sobre vías romanas en la mitad noroccidental de Galicia", Gallaecia, 20, 2001, páx. 217-248.

GAlsterer-Kröll, B., "Zum ius Latii in den keltischen Provinzen des Imperium Romanum”, Chiron, 3, 1979, páxs. 207-306.

GARCíA Y BELlido, A., "Parerga de arqueología y epigrafía hispano-romanas (iii)", 
Archivo Español de Arqueología, 39, 1966, páxs. 135-145.

—, "El llamado Itinerario de barro", Boletín de la Real Academia de la Historia, 172, 1975, páxs. 547-563.

Godineau, C., "Gaul”, en A. K. Bowman, E. Champlin e A. Lintott (eds.), The Cambridge Ancient History, t. X, Cambridge, 1996, páxs. 464-502.

GonzÁLEZ FernándeZ, J., "Ius Latii y Lex Flavia municipalis”, Mainaké, 23, 2001, páxs. 121-136.

KEAY, S., "Towns and Cultural Change in Iberia between Caesar and the Flavians", en L. Hernández Guerra, L. Sagredo San Eustaquio e J. M. Solana Sainz (eds.), La Península Ibérica hace 2000 años: actas del I Congreso internacional de historia antigua, Valladolid, 2001, páxs. 103-118.

KREMER, D., Ius Latium: le concept de droit latin sous la république et l'empire, Paris, 2007.

KulikowsKi, M., Late Roman Spain and its Cities, Baltimore, 2010.

LAMOINE, L., Le pouvoir local en Gaule romaine, Paris, 2009.

LE RouX, P., "Las ciudades de la Callaecia romana durante el Alto Imperio", Gerión, 14, 1996, páxs. 363-380.

- "Cultos y religión en el noroeste de la Península Ibérica en el alto Imperio Romano: nuevas perspectivas", Veleia, 26, 2009, páxs. 265-285.

Le Roux, P., e Tranoy, A., "Rome et les Indigènes dans le Nord-Ouest de la Péninsule Ibérique: problèmes d'épigraphie et d'histoire", Mélanges de la Casa de Velázquez, 9, 1973, páxs. 177-231.

Liebeschuetz, J. H. W. G., "Administration and Politics in the Cities of the Fifth to the mid Seventh Century", en A. Cameron, B. Ward-Perkins e M. Whitby (eds.), The Cambridge Ancient History, t. XIV, Cambridge, 2007, páxs. 207-237.

LOMAS SALMONTE, F. J., "Consideraciónes sobre las civitates del cuadrante noroccidental de la Península Ibérica", en A. Rodríguez Colmenero (coord.), Los orígenes de la ciudad en el noroeste hispánico, vol. I, Lugo, 1998, páxs. 171-192.

LóPez CueviLlas, F., "El municipio de Lais", Boletín de la comisión de Monumentos de Orense, XVIII, 2, 1955, páxs. 190-193.

MANGas MANJARrÉs, J., Aldea y ciudad en la antigüedad hispana, Madrid, 1996.

—, Leyes coloniales y municipales de la Hispania romana, Madrid, 2001.

Martín Valls, R., Romero Carnicero, M. V. e Carretero Vaquero, S., “Aras votivas de Petavonium”, Zephyrus, 48, 1995, páxs. 331-345.

MARTINO GARCíA, D., Las ciudades romanas de la meseta norte de la península ibérica: identificación, estatuto jurídico y oligarquías (ss. I-III d.C.), tese de doutoromento inédita (Universidad Complutense de Madrid), 2004.

MCELDERRY, R. K., “Vespasian's reconstruction of Spain”, Journal of Roman Studies, 8, 1918, páxs. 53-102.

MuÑIZ Coello, J., El sistema fiscal en la España romana (República y Alto Imperio), Huelva, 1980.

NiCOLS, J., "On the Standard Size of the Ordo Decurionum", Zeitschrift der SavignyStiftung für Rechtsgeschichte, 105, 1988, pp. 712-719.

ORTIZ DE URBINA, E., Las comunidades hispanas y el derecho latino: observaciones 
sobre los procesos de integración local en la práctica político-administrativa al modo romano, Vitoria-Gasteiz, 2000.

PASTOR MuÑoz, M., "Participación indígena astur en la vida social romana", Memorias de historia antigua, 1, 1977, páxs. 191-200.

Pereira Menaut, G., "Los castella y las comunidades de Gallaecia", Zephyrus, 34-35, 1982, páxs. 245-268.

—, "Un pobo e unha natio moi particulares", en G. Pereira Menaut (coord.), Galicia fai dous mil anos: o feito diferencial galego, vol. I, Santiago de Compostela, 1997, páxs. 237-249.

—, "Nuevas perspectivas sobre la vida de los castros galaico-romanos", Veleia, 22, 2005, páxs. 121-128.

PÉREZ LOSADA, F., "Entre a cidade e a aldea: estudio arqueohistórico dos aglomerados secundarios romanos en Galicia", Brigantium, 13, 2002 (volume completo).

PÉrez Pujol, E., Historia de las instituciones sociales de la España Goda, vol. II, Madrid, 1896.

Rivas Quintas, E. e Rivas Fernández, J. C. 1990, "El ara romana de Suatorre de Ambía (Orense) y sus inscripciones", Antigüedad y Cristianismo, 7, 1990, páxs. 567580.

RodríGuez COLMENERO, A., "Pueblos prerromanos del convento jurídico lucense: organización sociopolítica y distribución territorial”, en A. Rodríguez Colmenero (coord.), Lucus Augusti: el amanecer de una ciudad, vol. I, A Coruña, 1996, páxs. 129242.

- "Integración administrativa del Noroeste peninsular en las estructuras romanas", en A. Rodríguez Colmenero (coord.), Lucus Augusti: el amanecer de una ciudad, vol. I, A Coruña, 1996, páxs. 256-326.

—, "A organización sociopolítica do espacio: etnias e territorio", en AA.VV., Galicia Castrexa e Romana: Galicia Castreña y Romana, Lugo, 1997, páxs. 85-91.

Rodríguez Colmenero, A. e Ferrer Sierra, S., "Entre Bergidum Flavium y Asturica Augusta: nuevo hallazgo epigráfico y revisión de otro ya conocido", Larouco, 4, 2006, páxs. 244-246.

ROLDÁn HERVÁs, J. M., Itineraria Hispana: fuentes antiguas para el estudio de las vías romanas en la Península Ibérica, Valladolid, 1975.

SAlinas DE FRÍAS, M., Conquista y romanización de Celtiberia, Salamanca, 1986, páx. 207.

SÁnchez Albornoz, C., Ruina y extinción del municipio romano en España e instituciones que le reemplazan, Buenos Aires, 1943.

Santos Yanguas, J., Comunidades indígenas y administración romana en el noroeste hispánico, Bilbao, 1985.

SAnTOS YANGUAS, N., El ejército y la romanización de Galicia: conquista y anexión del noroeste de la Península Ibérica, Oviedo, 1988, páx. 233.

-, "Flavionavia: una ciudad romana en la frontera del Imperio", Studia Historicahistoria antigua, 16, 1998, páxs. 123-148.

SASTRE PRATS, I., Formaciones sociales y organización territorial en el Conventus Asturum: la integración en el mundo romano y el proceso histórico durante el Alto 
Imperio, tese de doutoramento inédita (Universidad Complutense de Madrid), 1999.

SARTRE, M., El oriente romano: provincias y sociedades provinciales del Mediterráneo provincial de Augusto a los Severos (31 a. de C.-256 d. de C.), Madrid, 1994.

SoEIRo, T., "O esplendor do Sur da Callaecia”, en G. Pereira Menaut (coord.), Galicia fai dous mil anos: o feito diferencial galego, vol. I, Santiago de Compostela, 1997, páxs. 213-236.

SuÁrez PiñeIro, A. M., A vida cotiá na Galicia Romana, Santiago de Compostela, 2006.

TARPIN, M., "Organisation politique et administrative des cités d'Europe occidentale sous l'Empire”, Pallas, 80, 2009, páxs. 127-145.

Teja Casuso, R., "La carta 67 de S. Cipriano a las comunidades cristianas de LeónAstorga y Mérida: algunos problemas y soluciones", Antigüedad y Cristianismo, 7, 1990, páxs. 115-125.

TrAnOy, A., La Galice Romaine: recherches sur le nord-ouest de la péninsule ibérique dans l'Antiquité, Paris, 1981.

—, "Permanences indigènes et romanisation en Galice", en AA.VV., Actas do I Congreso Internacional da Cultura Galega, Santiago de Compostela, 1992, páxs. 7780 .

UntermanN, J., "Anotaciones al estudio de las lenguas prerromanas del Noroeste de la Península Ibérica", en AA.VV., Galicia: da romanidade á xermanización: problemas históricos e culturais, Santiago de Compostela, 1993, páxs. 367-397.

UreñA, R., "El modius de Ponte Puñide", Boletín de la Real Academia de la Historia, 66, 1915, páx. 485-502.

VILlanUeVA ACUÑA, M., "O Ius Latii e a transformación do hábitat galaicorromano", en AA.VV., Galicia: da romanidade á xermanización: problemas históricos e culturais, Santiago de Compostela, 1993, páxs. 33-39.

—, "Da comunidade prerromana á galaicorromana: as fontes clásicas e a súa contribución para o problema”, en A. Rodríguez Colmenero, Los orígenes de la ciudad en el noroeste hispánico, vol. I, Lugo, 1998, páxs. 675-682.

Witschel, C., "Hispania en el siglo III", en J. Andreu Pintado, J. Cabrero Piquero e I. Rodá de Llanza (coords.), Hispaniae: las provincias hispanas en el mundo romano, Tarragona, 2008, páxs. 473-503.

\section{Corpora epigráficos citados}

$A E=L$ 'Année Épigraphique, Paris.

AF = Rodríguez COLMENero, A., Aquae Flaviae: fontes epigráficas da Gallaecia meridional interior, Chaves, 1997.

CIL II = HÜBNER, E., Corpus Inscriptionum Latinarum, t. II, Berlin, 1869.

CIL VIII = WILMANNS, G., Corpus Inscriptionum Latinarum, t. VIII, parte 1, Berlin, 1881.

CIRG I = PEREIRA MENAUT, G., Corpus de inscripcións romanas de Galicia, t. I, Santiago de Compostela, 1991.

ERA, = DiEgo SANTOS, F., Epigrafía romana de Asturias, Oviedo, 1959.

IRG II = VÁZQUEZ SACO, F. e VÁZQUEZ SEIJAS, M., Inscripciones romanas de Galicia, 
t. II, Santiago de Compostela, 1954.

IRG IV = LoREnzo Fernández, J., D'Ors, A. e BouzA Brey, F., Inscripciones romanas de Galicia, t. IV, Santiago de Compostela, 1968.

IRPLe = DIEGO SANTOS, F., Inscripciones romanas de la provincia de León, León, 1986.

IRPLu 24 = ARIAS VILAS, F., LE ROUX, P. e TRANOY, A., Inscriptions romaines de la province de Lugo, Paris, 1979.

RIT = ALFÖLDY, G., Die römischen Inschriften von Tarraco, Berlin, 1975.

\section{FIGURAS}

Figura 1. Mapa de referencia

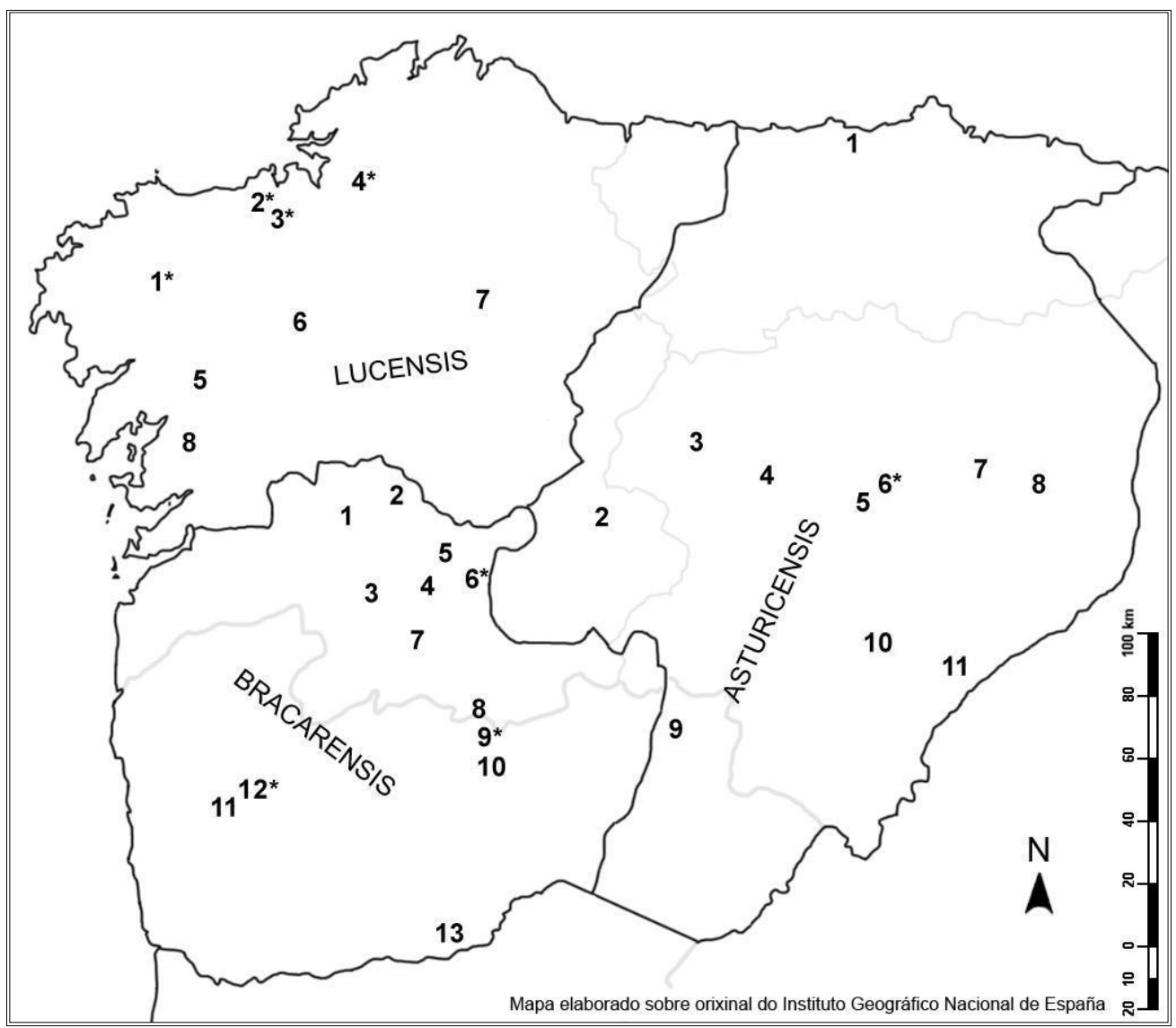

Relación dos topónimos citados no texto:

ASTORGA

1. Flauionauia; -2 . Forum Gigurrorum; - 3. Bergidum Flauium; - 4. Interamnium Flauium; - 5. Astorga; - 6 Uallatia; - 7. León; - 8. Lancia; - 9. Castro de Avelãs, Bragança; - 10. Rosinos de Vidriales; - 11. Brigiaecum.

BRAGA

1. Municipium Lais; -2 . Forum Bibalorum; -3 .

Castromao; - 4. Ambía Baños de Molgas; - 5 .

Asadur, Maceda; - 6. Forum Narbasorum; - 7. Xinzo de

Limia; ciuitas/Forum

Limicorum; - 8. Oímbra; - 9 Auobriga; - 10. Chaves; 11. Braga; - 12. Patria de Ulpio Réburo; - 13. Pinhão Alijó.

LUGO

1. Celticoflauia; -2

Brigantium Flauium; -3 . Klaudiomérion; - 4. Flauia Lambris; - 5. Iria Flauia; - 6 Ponte Puñide, O Pino; -7 . Lugo; - 8. Municipium Celenis.

O asterisco $(*)$ indica topónimos de localización insegura. 
Figura 2. Cidades con epítetos imperiais.

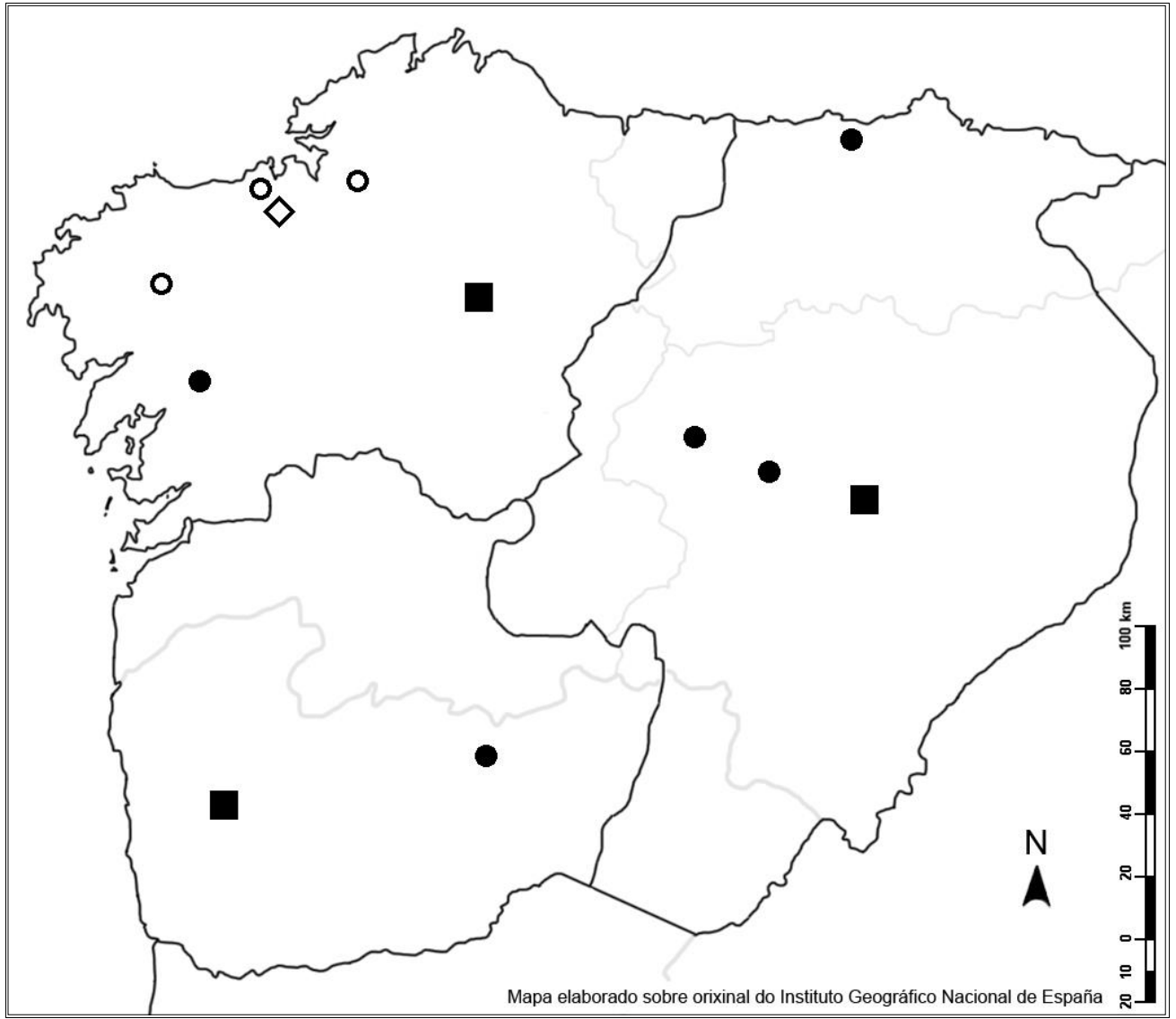

- Cidade augustea

- Klaudiomérion

- Cidade flaviana

Os signos baleiros

indican que a

localización é

insegura 
Figura 3. Testemuños da tribo Quirina

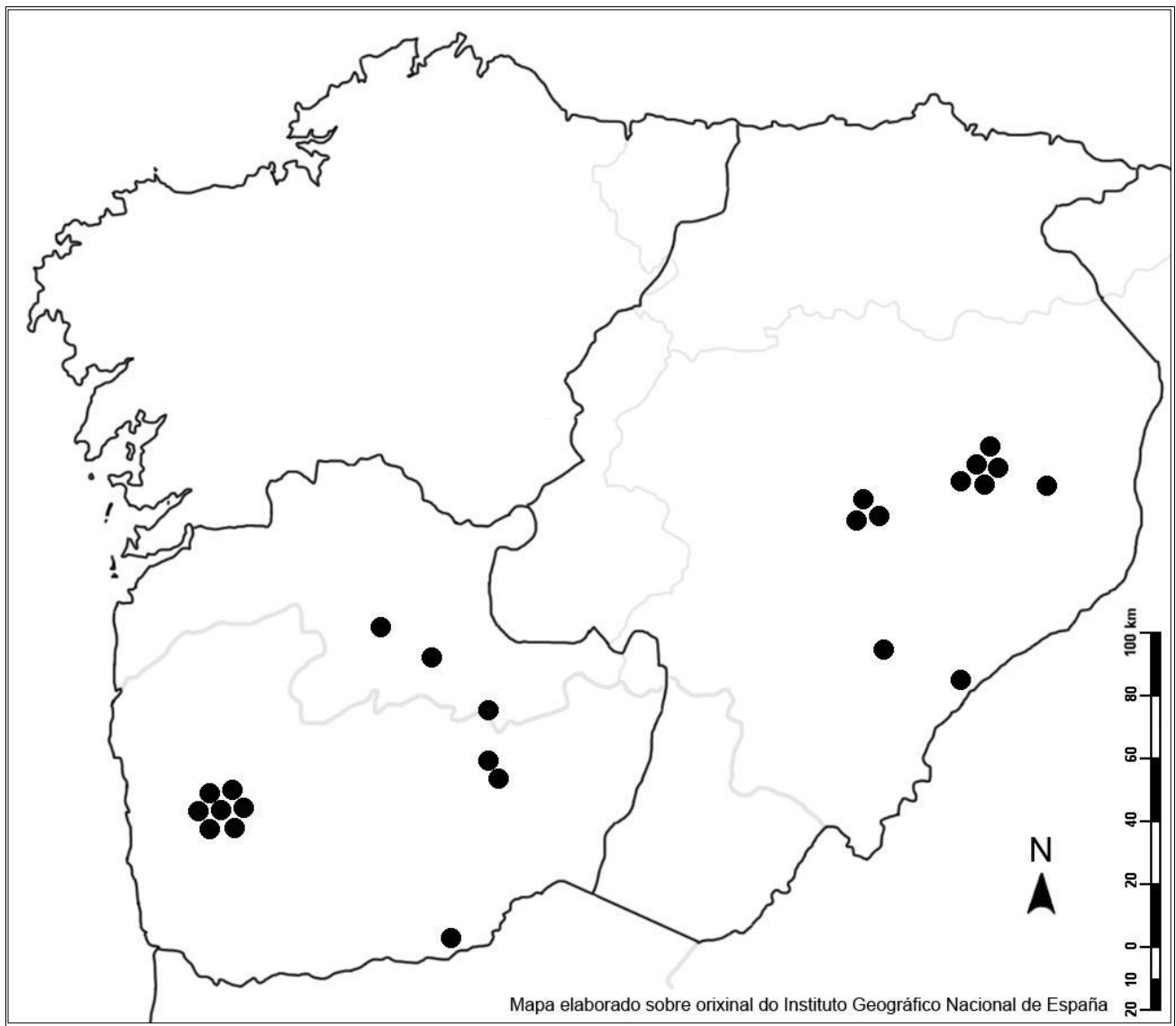

- Cada punto indica un testemuño epigráfico da tribo Quirina 
Figura 4. Institucións municipais constatadas.

\begin{tabular}{|c|c|c|c|c|c|c|c|c|c|c|c|}
\hline LOCALIDADE & ciuitas implicada & augur & $\begin{array}{c}\text { curator rei } \\
\text { publicae }\end{array}$ & duumuir & flamen & legatus & lictor & magister & ordo & tabularius & $\begin{array}{c}\text { cursus } \\
\text { honorum }\end{array}$ \\
\hline S. Eufemia Ambía & incerta & & & & $x$ & & & & & & \\
\hline Asadur & Interamici & & $\mathrm{x}$ & & & & & & & & \\
\hline \multirow{3}{*}{ Astorga } & Asturica Augusta & \multirow{2}{*}{$x$} & & $x$ & $x$ & & & $x$ & & & \\
\hline & Uallatia (?) & & & & & & & & & & \\
\hline & \multirow{2}{*}{ Zoelae } & & & ? & & & & & & & \\
\hline Castro de Avelãs & & & & & & & & & $x$ & & \\
\hline Braga & Bracara Augusta & & & & $\mathrm{x}$ & & & & $\mathrm{x}$ & & \\
\hline Chaves & Aquae Flauiae & & & & & $x$ & & & $x$ & & $x$ \\
\hline Castromao & Coelerni & & & & & $\mathrm{x}$ & & & & & \\
\hline León & Legio VII & & & & & & $\mathrm{x}$ & & & & \\
\hline Lugo & Lucus Augusti & & & & $x$ & & & & $x$ & $x$ & \\
\hline Ponte Puñide & Copori? & & & & & & & & $x$ & & \\
\hline \multirow{7}{*}{ Tarragona } & Aquae Flauiae & & & & & & & & & & $\mathrm{x}$ \\
\hline & Auobriga & & & & & & & & & & $x$ \\
\hline & Bracara Augusta & & & & & & & & & & $\mathrm{x}$ \\
\hline & Brigiaecum & & & $x$ & & & & & & & $\mathrm{x}$ \\
\hline & Lancia & & & $x$ & & & & & & & $x$ \\
\hline & Limici & & & $\mathrm{x}$ & & & & & & & $x$ \\
\hline & incerta & & & & & & & & & & $x$ \\
\hline
\end{tabular}

Figura 5. Localización das institucións municipais.

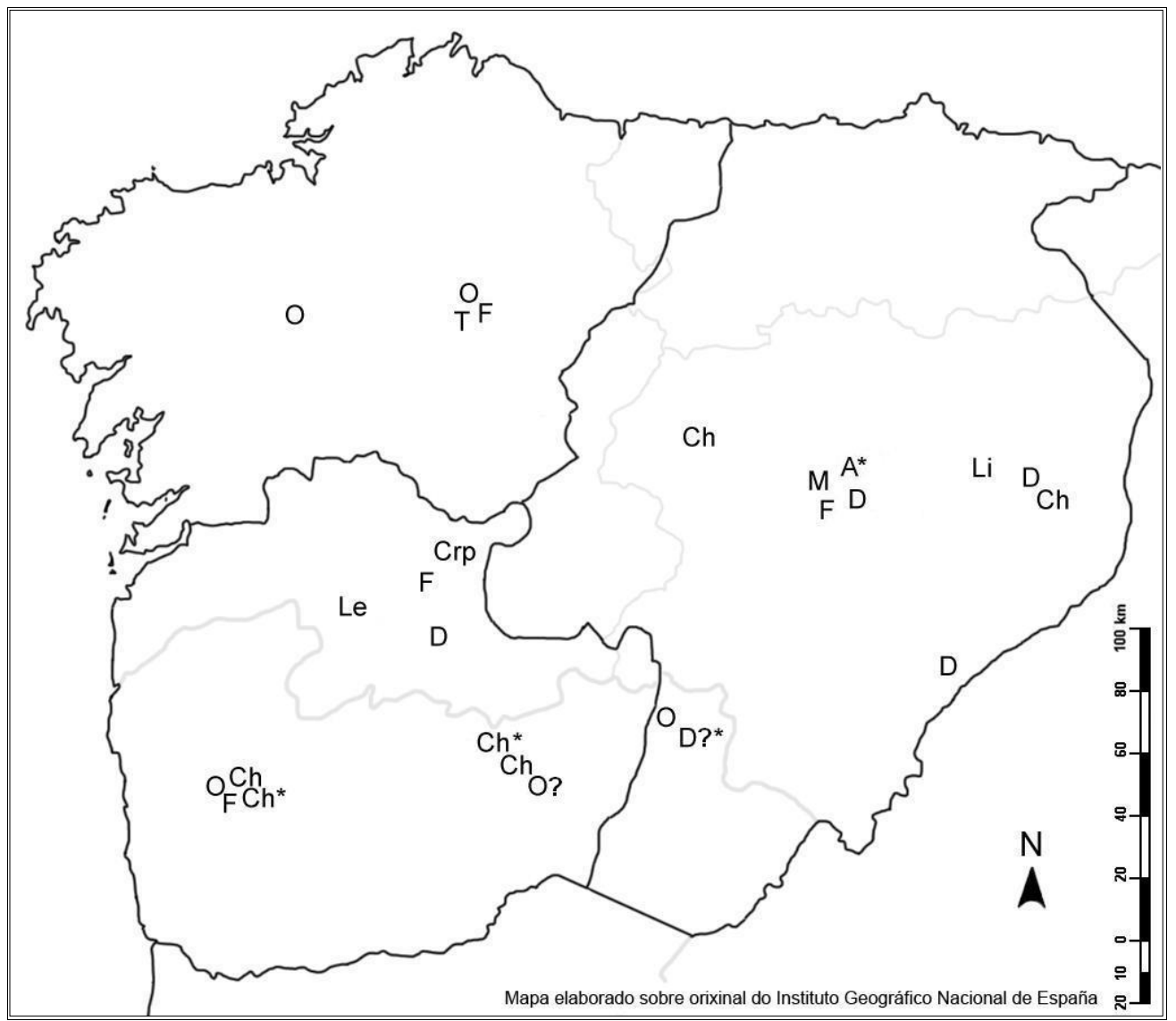

Indícase cunha inicial a localización da referencia institucional $\mathrm{A}=$ augur $\mathrm{Ch}=$ cursus honorum Crp $=$ curator rei publicae

$\mathrm{D}=$ duumuir $\mathrm{F}=$ flamen Le $=$ legatus $\mathrm{Li}=$ lictor $\mathrm{O}=$ ordo decurionum $\mathrm{T}=$ tabularius O interrogante (?) indica inseguridade do testemuño. 
Figura 6. Títulos constitucionais constatados.

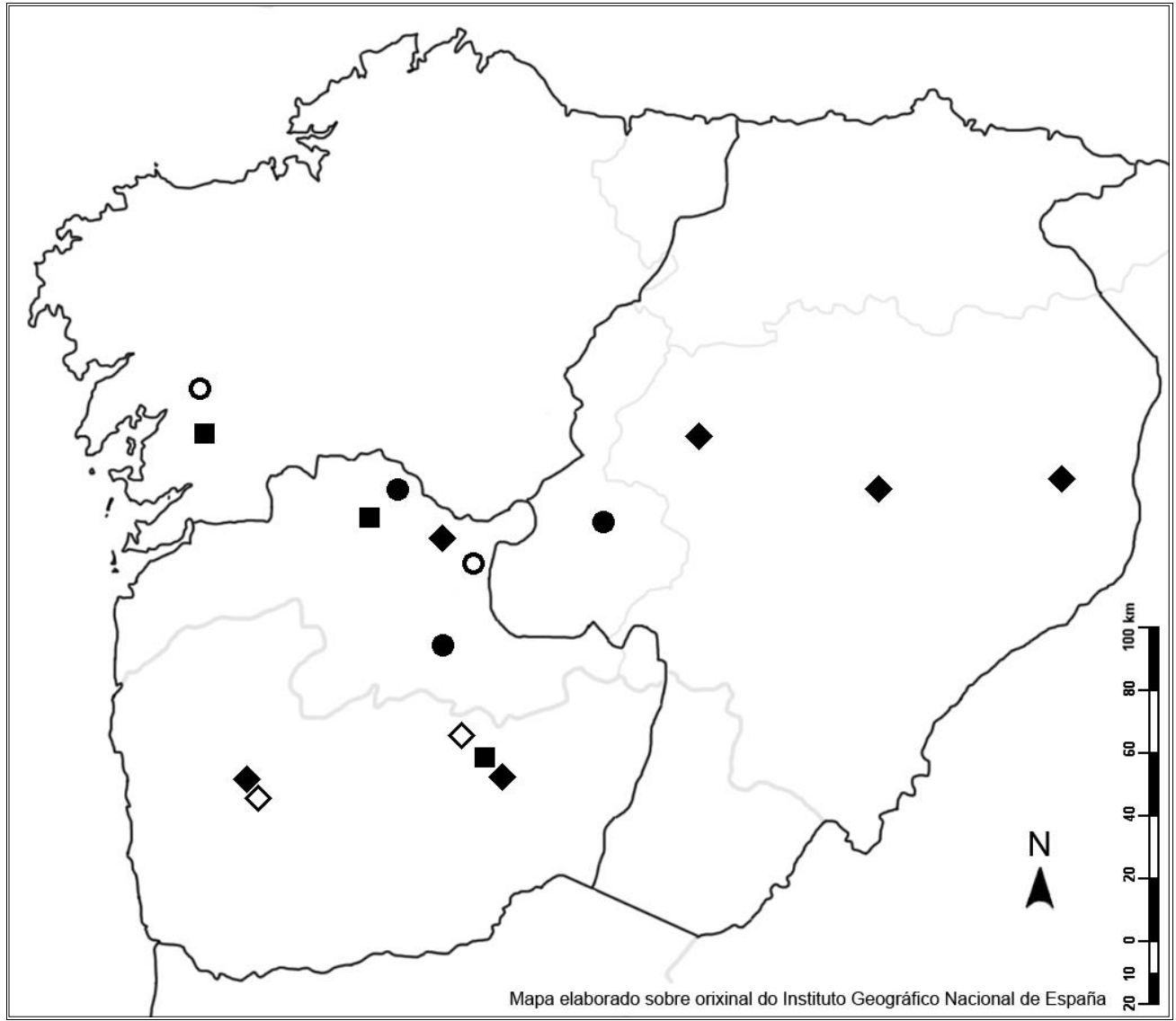

- Municipium

- Res publica

- Forum

Os signos baleiros indican localización ou veracidade insegura. 
Figura 7. Localización de todos os testemuños estudados.

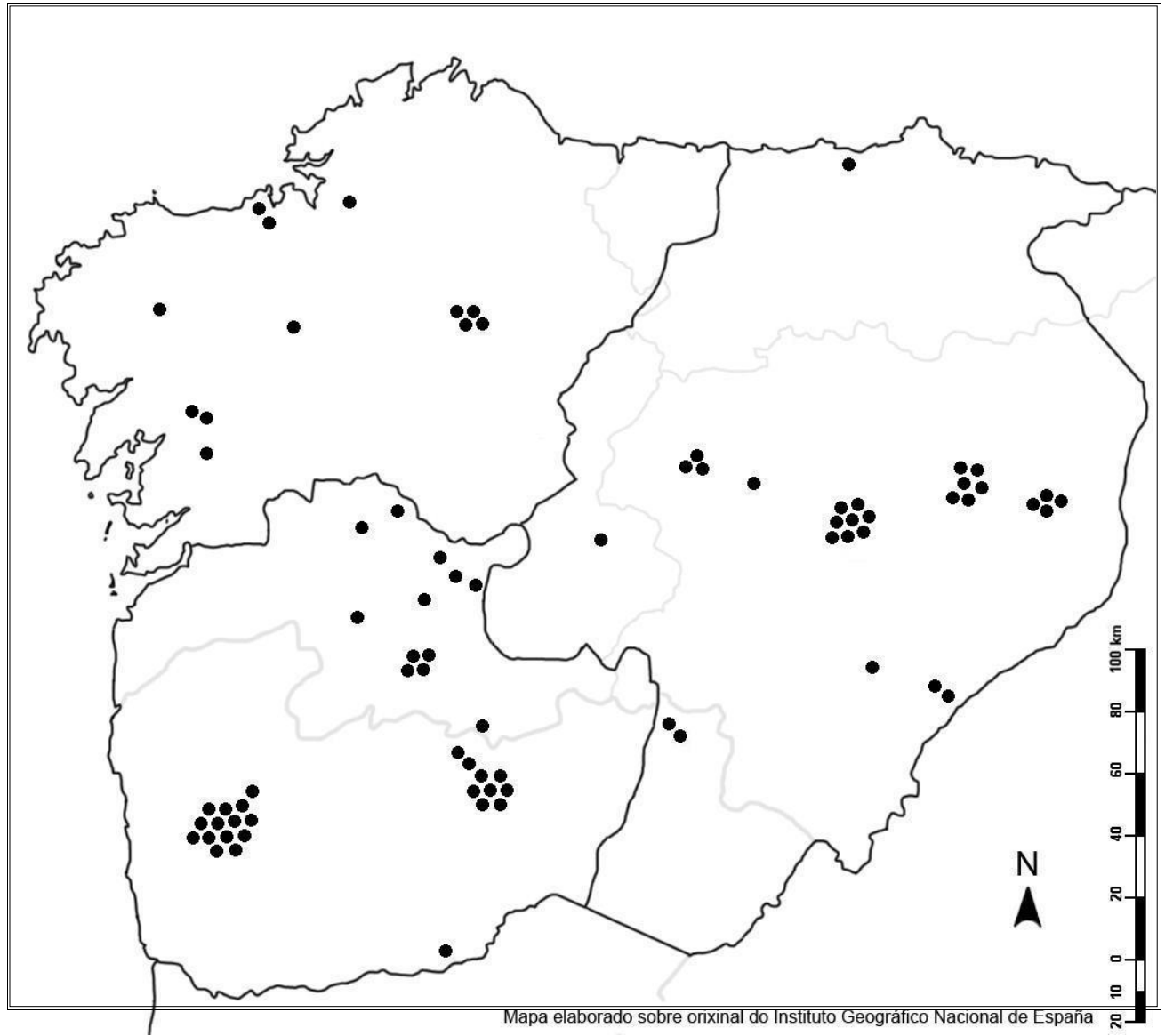

- Cada punto indica unha referencia vencellada ao tema da municipalización da Asturia et Callaecia tratada ao longo do estudo 